\title{
Photovoices of Urban Educational Leadership Students Abroad in Peru
}

\author{
W. Kyle Ingle \\ University of Louisville \\ Detra Johnson \\ University of Houston
}

\begin{abstract}
:
The purpose of this qualitative study was to examine the perceptions and experiences of educational leadership graduate students who participated in a short-term study abroad program in Peru. We analyzed assignments submitted for course credit, including a total of 144 photos and 107 corresponding reflections submitted as part of the photovoice assignment. Analysis revealed that the study abroad was a transformative experience. Students drew upon their own professional experiences to make sense of their educational experiences overseas. Their experience in Peru gave them a window into the world of so many students in their U.S. schools - what it is like to be a racial and language minority-enriching and informing their perspectives as educators and future educational leaders. Instructors in study abroad courses may seek a balance between the analytical constraints of applied heuristics with the freedom that photovoice promises.
\end{abstract}

\section{Introduction}

Lindsey et al. (8) contend that culturally competent school leaders understand that effective leadership in diverse environments requires changing the manner in which they work with those who are culturally different from themselves. Scholars (e.g., Fine and McNamara 256) posit that in order to transform schools and districts into pluralistic, inclusive environments, educational leaders must examine their own tacit assumptions about the diverse students with whom they work. One of the ways that educational leaders (pre-service and in-service) may do so is to participate in study abroad experiences. Such experiences offer the opportunity for participants to familiarize themselves with other educational policy and practice contexts — as well as experiencing life (albeit briefly) as a language and/or ethnic minority in the host country.

Hallinger and Chen note a growing need to explore leadership practices critically and comparatively (21). Whether undertaking empirical research studies internationally (or facilitating educational leadership courses abroad), such international perspectives have the potential to build collaborative partnerships, foster the development of global leadership competencies, and inform teaching and learning in educational leadership, thus expanding the knowledge base (Normore and Erbe xix). All of these aid in identifying and applying effective practices in other educational leadership contexts (Brooks and Normore 72). Given the demands on educational leaders to lead schools in increasingly diverse and complex communities, the provision of short-term study abroad programs is a way to facilitate such preparation beyond the classroom. Indeed, Richardson et al. noted that, "The notion of taking graduate students abroad seems to be all but ignored by most preparatory programs as evidenced by the lack of research literature" (95). Furthermore, there have been calls to explore the 
quality and benefits of study abroad experiences beyond the numbers of students participating in such programs (Engle and Engle 18). Lastly, researchers (Werts et al. 822) note that photovoice is a methodological strategy that provides participants an opportunity to explore phenomena in a unique way that traditional methods of research may not. Werts et al. state that, "Photovoice is one tool that engages leaders and future leaders in reflection and growth on the complexity of leading in our accountability driven policy environment" (839). Responding to these calls, we sought to answer the following research questions: Using photovoice, how do participating students make sense of educational and cultural experiences in a short-term study abroad? In what ways did participating students perceive the short-term study abroad experiences as shaping and informing their knowledge of educational leadership?

\section{Study Abroad-A Review of the Literature}

Study abroad experiences provide a means of learning beyond the classroom (McPhail et al. 372; Sjoberg and Shabalina 47) and becoming immersed in a new culture (Andrews and Henze 8). Teichler and Steube found that students who participated in study abroad experiences reported increased skills in navigating unfamiliar cultures, speaking a foreign language, thinking critically, and wanting to participate again in other study abroad opportunities (340). Participants describe such experiences as transformational, helping to prepare them for "global citizenship" in an increasingly interconnected and multicultural twenty-first century (Colville-Hall et al. 275; Fine and McNamara 263). Although research suggests that participant perceptions of study abroad experiences are overwhelmingly positive, findings are mixed as to whether study abroad experiences are statistically associated with successfully attaining gainful employment (e.g., Di Pietro 233; Orahood et al. 124; Wiers-Jensen 91).

In the context of educator preparation (e.g., foreign languages) and business programs, the extant research on study abroad experiences is generally positive in terms of learning outcomes and developing human capital (Castañeda and Zirger 558; Womble et al. 108). In the case of teacher preparation programs, study abroad programs are a means of preparing a predominantly White teacher workforce to work with increasingly diverse students, developing global perspectives among preservice teachers, and raising preservice teachers' awareness of social justice issues (Phillion et al. 336). There is evidence to suggest that such programs are successful in achieving these aims (e.g., Hill and Thomas 204; Relich and Kindler 77; Sleeter 216). For example, Hill and Thomas's study of Australian teacher education students provides evidence of the unplanned outcomes of such programs (202). Hill and Thomas discussed the development of a critical perspective towards media constructions of "otherness" among Australian students who participated in an intensive Indonesian language program. The study abroad program occurred prior to the Bali nightclub bombings that killed (among many others) a large number of Australian tourists (200). The students' experiences in Indonesia positively influenced the perceptions of their former hosts and greatly increased their concerns that media constructions of Indonesians in the Australian press were unchallenged and unfairly negative. Phillion et al. found that study abroad experiences provided preservice teachers with an intellectual and critical starting point for multicultural awareness of the educational, social, and political relationships in their lives and in the lives of others from cultures different from their own (335).

The aforementioned studies are qualitative in their methodological approach, drawing from relatively small number of participants in programs. However, Paige et al. undertook a longitudinal study of more than 6,000 students who participated in study abroad experiences, finding that such 
students are more likely to become globally engaged citizens and that the length of time abroad was not associated with levels of global engagement, suggesting that it is the quality of pre-planning and the experience itself that is associated with global engagement (S40).

Research suggests that educational leaders have an indirect impact on their schools' student achievement (Grissom et al. 23). School leaders realize these positive impacts by charting a course for the school and those they lead toward a shared vision and mission, setting high expectations for teachers and students, by using data to track performance and shape decision-making, and by providing supports for teachers (Leithwood et al. 3). U.S. student populations are increasingly racially and ethnically diverse-even as teachers and educational leaders remain predominantly White. Teachers and educational leaders must strive to make the educational environment relevant to the student population if they are to realize positive student outcomes for their student body as a whole and for the various subpopulations - for the good of these students and because federal and state accountability systems demand it (Goldenberg 112). As such, the skills and dispositions of school leaders, whether innate or learned, are integral to achieving positive outcomes, albeit indirectly.

Researchers highlight the importance of learning beyond the classroom (McPhail et al. 372; Sjoberg and Shabalina 47). With regard to the role of study abroad experiences in educational leadership programs, the extant research is sparse. We found only two studies-one mixed-methods and one quantitative. Jayson Richardson and colleagues author both of these. Richardson, Imig, and Ndoye undertook a mixed-methods study of an international practicum for masters and doctoral students in educational leadership. Richardson, Imig, and Ndoye asked three research questions (99). First, they asked if the international practicum increased the participants' awareness and acceptance of similarities and differences among people. Second, they asked if participants experienced shifts in awareness and acceptance of similarities and differences differently than those preservice school leaders who did not engage in such an experience. Lastly, Richardson, Imig, and Ndoye asked what might explain shifts in awareness and acceptance of similarities and differences (to the extent that these existed)? Richardson, Imig, and Ndoye compared the results from the Miville-Guzman UniversalityDiversity Scale (MGUDS) survey of seven master's degree seeking students who participated in a study abroad experience in the United Kingdom with eleven master's degree students who did not. The researchers administered the survey to the treatment and control group two times-prior to the study abroad experience and after a period of six months after the treatment group's return from overseas. Qualitative data was also compiled in the form of submitted pre-departure assignments, online and face-to-face discussions focusing on diversity awareness, cultural adaptation, and cultural conflict, lessons learned about the education system, and general issues of adaptability to the host culture. Finally, the researchers interviewed the members of the treatment group individually.

Richardson, Imig, and Ndoye found that the international practicum increased the participants' awareness and acceptance of similarities and differences among people in comparison to the control group. Their analysis also revealed that participants' notions of diversity expanded as a result of the study abroad experience, realizing that diversity encompasses more than race, and includes values, ethics, ethnicities, national identity, sexuality, lifestyles, and political views. Richardson, Imig, and Ndoye found evidence that participants reported becoming more comfortable with differences and a realization that their prior experiences with diversity were limited (117). 
In a follow-up study, Richardson, Imig, and Flora focused on the growth scores of the participants using the MGUDS results and its three subscales: (1) a Relativistic Appreciation of oneself and others; (2) seeking Diversity of Contact with others; and (3) a Comfort with Differences with the larger society. Their analysis revealed that although the group of students decreased on each of three individual subscales of the instrument from the pre- to post-test, the qualitative data indicated that the "downward shift was not necessarily a bad thing. It was, however, an indicator that students' perceptions of self and others were morphing" (366). Richardson et al. found that the ways in which students are introduced to the experience, supported during the experience, and provided with opportunities to debrief after the experience concluded shape quality of the student experience (365). These include providing a wellstructured pre-departure experience that prepares the students in advance of this experience, wellstructured experiences while overseas, and opportunities to reflect on their learning after returning home. In sum, prior planning, preparation and the development of clear course learning outcomes assignments matter if the participants are to become globally minded school leaders.

Evidence suggests that the numbers of students (undergraduate and graduate) participating in study abroad experiences have increased over time (Institute of International Education 27). Engle and Engle have called for the focus to shift "from an appraisal of the sheer numbers of students participating in international education to the quality of their experiences abroad" (1). Given that researchers (Paige et al. S29-S41) found that the quality of study abroad planning and experiences are important to outcomes, it is important to explore how students perceived the quality of the experiences and how such experiences shaped them as educational leaders.

\section{Photovoice}

When participating in study abroad experiences — and travel, more generally-one of the items likely be taken on the trip is a camera. Whether its own device or a function on a cellphone, a camera is a way for the user to capture a moment, a memory, and a place in time through a photographic image. Photomethods, including photovoice and digital storytelling, are methodological strategies that utilize photography as a means of data collection and exploration of lived human experiences. Perhaps Barndt summarized the essence of photovoice best, stating:

Photovoice puts cameras in the hands of those who traditionally might have been identified as the 'research subjects', offering them an opportunity to be active participants in the research process, inviting them to 'voice' their experiences, perspectives and analyses through the photographs that they take. (620)

Scholars (e.g., Barndt 620; Julien et al. 258) have noted that photovoice traces its roots back to Paulo Freire's theories of empowerment education, feminist theory, and documentary photography. Freire encouraged individuals and communities to be active, rather than passive, participants, thus seeking to increase empowerment and engagement (155). Similarly, feminist theory seeks to provide a voice to women, who are too often under-represented and marginalized. Documentary photography has long sought to capture the power and significance of a moment in time through images. Photovoice consists of a simple two-stage process by which participants first take photographs and select photographs. Participants then discuss the selections, thus providing a means of capturing multiple perspectives on place experiences and understandings (Annang et al. 241; Chanse et al. 109). Photovoice plays an important role in place-based education (Briggs et al. 153; Chanse et al. 109). Photovoice has been utilized in a number of fields, such as gender studies (Thompson 65), 
health/health education (Annang et al. 242; Mamary et al. 359), social work (Kelley 185; Mayan et al. 107), and education (Chanse et al. 109; Jackson 255; Werts and Brewer 206; Werts et al. 817; Zenkov and Harmon 575).

In the realm of educational leadership, its use is limited. Werts and colleagues undertook two photovoice studies, both exploring the experiences of school principals as implementers of policy (817; 206). Werts et al. engaged two South Carolina principals-one elementary and one high school (817). Through photographs, the two principals revealed two distinct perspectives on being policyimplementing principals. One perceived her high school as an entropic world where policy situations cross through, around, and within her physical and mental reach. The other perceived himself as having multiple identities_one as a principal and the other as a community leader. Werts et al. acknowledged qualitative research studies with small sample sizes such as their own are not generalizable, but generalizability is not the goal of such research designs. As Werts et al. noted, "Research using photography and digital media has the opportunity to contribute to configurational validity or the layering of data to help grasp a larger picture" (838).

Drawing from Ranciere and Merleau-Ponty's theorizations on democracy, Werts and Brewer undertook a follow-up study that sought to understand the lived policy experiences of four elementary school principals and policy-implementing educational leaders (206). They found that policy implementation at the building level is fraught with politics and a spatially inhabited practice involving negotiation and strategy, wherein prior experiences moderate and appropriate policy. Werts and Brewer reframe the work of principals as policy implementers, privileging principals' representations of their lived experiences through photography in an effort to capture how they experience policy in each of their unique locations.

\section{Understanding Organizations: Bolman and Deal's Four Frames}

Organizations, whether educational, corporate, or non-profit, are complex. Organizations found within an international context different than one's own add another dimension to the complexity. Drawing on social and cultural anthropology, Bolman and Deal developed a four-frame model (see Figure 1) to serve as "filters for sorting essence from trivia, maps that aid navigation, and tools for solving problems and getting things done" (21). The structural frame focuses on the architecture of the organization. Structural frame factors include aspects of an organization, such as the hierarchy of the organization, divisions of labor within the organization, policies, and procedures. The human resource frame emphasizes the roles that people play within organizations, for example, their needs, skills, relationships, morale, and motivations. The political frame examines organizations through the lens of competition for power, advantage, limited resources, and interests. The symbolic frame views organizations as environments with their own cultures, rituals, ceremonies, and symbols. 
Figure 1. Frame-Related Issues and Areas of Focus (Bolman \& Deal, 2013)

\begin{tabular}{|l|l|}
\hline Frame & Frame-Related Issues/Features \\
\hline Structural & $\begin{array}{l}\text { rules, regulations, goals, policies, roles, tasks, job designs, job descriptions, technology, chain of command, } \\
\text { vertical and horizontal coordinating mechanisms, assessment and reward systems, standard operating } \\
\text { procedures, authority spans and structures, spans of control, specialization/division of labor, information } \\
\text { systems, management processes }\end{array}$ \\
\hline $\begin{array}{l}\text { Human } \\
\text { resource }\end{array}$ & $\begin{array}{l}\text { needs, skills, relationships, norms, perceptions and attitudes, morale, motivation, training and development, } \\
\text { interpersonal and group dynamics, supervision, teams, job satisfaction, participation and involvement, } \\
\text { informal organization, support, respect for diversity, formal and informal leadership }\end{array}$ \\
\hline Political & $\begin{array}{l}\text { key stakeholders, divergent interests, scarce resources, areas of uncertainty, individual and group agendas, } \\
\text { sources and bases of power, power distributions, formal and informal resource allocation systems and } \\
\text { processes, influence, conflict, competition, politics, coalitions, formal and informal alliances and networks, } \\
\text { interdependence, control of rewards and punishment, informal communication channels }\end{array}$ \\
\hline Symbolic & $\begin{array}{l}\text { culture, rituals, ceremonies, stories, myths, symbols, metaphors, meaning, spirituality, values, vision, } \\
\text { charisma, passions and commitments }\end{array}$ \\
\hline
\end{tabular}

When used collectively, Bolman and Deal's four frames allow individuals (leaders or any other stakeholder) to view organizations through multiple perspectives and facilitate organizational sensemaking. First published in 1984, Bolman and Deal's book, Reframing Organizations: Artistry, Choice and Leadership, has since become a classic and required textbook in graduate educational leadership courses and advanced organizational theory courses. The framework has been used in an array of organizations and sectors, including institutions of higher learning (Fleming-May and Douglass 389, Stephenson 58), P-12 education (Dollarhide et al. 263; Flessa 342), churches (Barnes 986), non-profits (Heimovics et al. 419), and business (Hischheim and Newman 34).

Given that the context of our present analysis is a study abroad program situated in a public university, we focus our review of empirical studies utilizing Bolman and Deal's four frames in postsecondary settings. Fleming-May and Douglass applied the theoretical framework in the context of academic librarians in order to understand the dynamics, tensions, and implications of being a librarian in a university setting. Fleming-May and Douglass found that librarians' political and symbolic conditions are rooted in structural and human resource factors controlled by upper-level administration in both libraries and the universities. By addressing areas over which academic librarians have the most control (the political and symbolic frames), librarians may seek changes in the perceptions of status in the university community by seeking to increase their esteem among faculty in the disciplines, potentially yielding changes in the structural and human-resource frames.

Drawing upon Bolman and Deal's theoretical framework, Stephenson undertook a qualitative study that examined the dynamics of continuing higher education units within the sociopolitical context of higher education institutions (four private and four public). Drawing upon interviews with seventeen university administrators and document analyses, Stephenson found that in spite of differences in accountability among their constituencies, both public and private universities are complex and mission-driven. The symbolic frame is key for leaders to develop alternative organizational approaches to governance, cultural, and other relational issues within universities 
characterized by rigidity and traditions. Doing so promotes an alternative to continuing higher education units being perceived as "simply marketing arenas" and promoting a co-academic image (70).

Sowell applied Bolman and Deal's four-frame model to the context of the Collections and Resource Sharing Department at Oregon State University Libraries in the wake of a reorganization. Due to a fiscal crisis, Oregon State University reorganized the unit in order to consolidate staff from the circulation, acquisitions, interlibrary loan, collection maintenance, and collection development subunits. Specifically, Sowell sought to make sense of the reorganization retrospectively through the lens of Bolman and Deal's four-frames to determine whether the framework continued to evolve the paradigm for collection management. Sowell noted the propensity for managers to develop organizational change with an overemphasis on structural factors (e.g., division of labor and the organizational architecture). The result is that "too often, proposed changes do not succeed because of lack of attention to human needs, existing power structures, and inherent symbolism of existing and proposed organizational arrangements" (211). Sowell found the political and symbolic frames emerged as important lenses for libraries in responding to changes in cultural values and power structures. He noted the need of academic libraries to develop a new paradigm for collection management in order to transition the organization ably.

We were unable to find any published peer-reviewed research studies that applied Bolman and Deal's framework to the specific context of study abroad experiences and programs. However, Flessa describes Bolman and Deal's theoretical framework as "one of the most accessible overviews of how to use different conceptual frames to understand managerial and leadership issues within organizations; their work is influential in educational leadership circles because it is frequently taught in educational administrator preparation and development programs" (342). Indeed, Bolman and Deal's text was a required text for the students that participated in the Peru study abroad experience. A majority of them were familiar with or had the text already, as it was required reading in another course in their program of study.

\section{Methods}

\section{The Context-Study Abroad Experience in Peru}

The study abroad experience in Peru was a graduate-level course offered by a doctoral granting, research-extensive urban university in the summer of 2015. The stated purpose of the course was to offer a graduate study abroad experience in which educational leadership students undertake an intercultural immersion in Peru, visiting multiple Peruvian educational organizations, visiting with stakeholders (primary, secondary, tertiary, governmental, and non-profit), and participating in lectures/discussions with university faculty, ministry officials, administrators, teachers, and students. The course offered the students an opportunity to learn about international perspectives on leadership preparation, leadership practice, and Peruvian education policy. The experience also afforded opportunities for the students to contribute as active participants at the school sites they visited, benefitting both the students and the hosting educational sites. The U.S. study abroad participants contributed to instruction by serving as guest speakers, answering questions from students, teachers, and administrators about instruction and their schools in the United States. Students also contributed school supplies and monetary donations to the two rural Andean schools that hosted the study abroad students. In the case of one remote Andean school site, the U.S. study abroad students hiked to the school site laden with school and food supplies for delivery. The university faculty provided letters 
recognizing the service contributions of Peruvian faculty, Ministry of Education officials, and nonprofit representatives who served as lecturers and facilitators for the U.S. study abroad students.

Two university personnel accompanied the students on the study abroad experience. One was the instructor of record, a U.S. citizen who had no prior experience in or travel to Peru, but had participated in study abroad experiences in Europe and undertaken international research in Europe and Central America. The other was a university staff member. This individual, a native Peruvian fluent in Spanish, served as a recruiter/point of contact for those interested in enrolling in the experience. This individual was also responsible for the logistics of the trip, working with travel agents to arrange flights, tours, accommodations, and in-country transportation. This individual was also responsible for arranging meetings, seminars, site visits, and discussions facilitated by Peruvian school administrators, local faculty, and Ministry of Education officials. The two university personnel who facilitated the study abroad experience had all of their expenses paid, but were not paid for instruction. The university passed along these savings, along with other university resources, to students in the form of scholarships to defray the costs of the experience.

The course, classified as short-term study abroad experience by Engle and Engle, consisted of three basic stages: Pre-Departure, Study Abroad Experience, and Post Experience Debriefing (11). The predeparture stage consisted of meetings between the students, the instructor of record, and university staff members. At these pre-departure meetings, the students received pre-departure orientation materials, such as the itinerary and syllabus (see Appendix A). Additionally, students attended predeparture lectures on Peruvian culture, government, and education, and faculty members facilitated discussions of assigned readings on Peruvian education (e.g., World Bank) and photovoice methods (Werts et al. 824). These meetings also served as a chance for students to ask questions about the upcoming experience and the assignments. Also part of the pre-departure stage, students submitted a 3-page (minimum) pre-departure paper. In this assignment, students reflected upon their prior knowledge and preconceptions of Peru, its people, and culture; what they expected to see and experience in Peru; what they were interested in learning more about once they arrived (e.g., specific aspect(s) of education and leadership); and why they were interested in these specific aspects.

In terms of the study abroad experiences, there were two main geographic areas of focus: Lima and Cusco. These were selected due to their importance historically, culturally, and economically, but also because the two cities and surrounding regions provided an opportunity to compare and contrast the experiences and conditions that exist between them. The two Peruvian cities and surrounding regions differ in terms of wealth and socio-demographics. As the nation's capital and largest principal city, Lima is an important center of government, finance, industry, and culture. There, Spanish is the predominant language. Cusco is important historically, culturally, and economically in its own right. Indeed, Cusco is a UNESCO World Heritage site (UNESCO)_-but unlike Lima, it is a city high in the Andes Mountains with a large number of Quechua-speaking residents. While both cities have residents living in poverty, the Andean region in which Cusco is located is more remote and has higher levels of rural poverty.

In both cities, students participated in tours, visited important historical, cultural, and tourist sites (e.g., museums, government buildings), and visited elementary and secondary school sites (both state and private). In addition to tours of the facilities and meetings with teachers, students, and 
administrators, the study abroad students were able to observe school activities and serve as guest lecturers, answering questions from Peruvian students and educators. Students also attended lectures and discussions with Peruvian higher education faculty as well as non-profit and governmental officials. These provided an opportunity to learn about such topics as the historical development of educational institutions in Peru, trends in educational policy and practice, and the role of education in the ongoing development of the Peruvian economy.

As a follow-up to site visits and activities on the itinerary, the participating graduate students were expected to debrief daily in both formal and informal group meetings of students and university personnel. Following Inman et al., students were required to keep and submit reflective journals in order to increase "sensitivity and awareness of learning and functioning in a culture different from one's culture of origin" (17). As a way of making sense of the Peruvian educational context and organizations, students were expected to take photographic images of Peruvian stakeholders, educational environments, and their experiences in order to invoke "deeper elements of the human consciousness than text alone" (Harper 13). Among these photographic images, students were tasked with selecting, captioning, and submitting photos that represented their experiences. Finally, in the post-experience stage, students were expected to submit an 8-10 page (minimum) double-spaced paper on a student-selected topic of interest. In this paper, the students were to discuss the similarities and differences in educational leadership and educational policy between the United States and Peru, drawing upon relevant extant research as well as documents collected in Peru.

\section{Data Sources and Analysis}

Our qualitative data consisted of the four course assignments submitted by the students for course credit. As such, our qualitative study utilized document analysis as our analytical strategy. The photovoice assignment served as the centerpiece of the data collected. In total, 144 photos and $107^{1}$ corresponding reflections were submitted in response to the photovoice assignment. The other course requirements served as a way of triangulating the students' perceptions through other means.

All four students who participated in the short-term graduate study abroad program in Peru were female in-service teachers in a large urban school district pursuing graduate educational leadership degrees at an urban research university. In terms of teaching roles, one was an elementary teacher, one was a middle school teacher, and two were high school teachers. All students had prior overseas travel experiences; three had participated in study abroad programs previously, but none of the students had ever been to Peru.

Students were required to read and familiarize themselves with Bolman and Deal's (2013) Reframing Organizations: Artistry, Choice, and Leadership, $5^{\text {th }}$ Edition before departing for Peru. Bolman and Deal's four frames (structural, political, human resource, and symbolic) served as a recommended theoretical framework for students to make sense of their short-term study abroad experience. Students were not solely constrained to using this framework. Given this recommendation, Bolman and Deal's four frames served as source of theory-driven, deductive coding. To these initial codes, we added codes inductively through iterative coding of documents. All of the student assignments were analyzed using NVivo 10 qualitative analysis software.

\footnotetext{
${ }^{1}$ Some students included multiple photos to accompany one specific individual reflection.
} 
As another means of triangulation, the two individual members of the research team independently analyzed the submitted course assignments in order to ensure inter-coder reliability (e.g., Tinsley and Weiss 358; 95). We analyzed assignments in stages. We chose to code the documents in the order of their submission in the class. First, we coded the pre-departure reflection papers, then the photovoice assignment, followed by the reflective journals, and the final paper. We coded each set of course assignments independently. We used an iterative team memo-writing process in our analysis, independently summarizing our findings and trends within the specific assignments. After we independently analyzed a set of assignments, we independently wrote a corresponding memo, meeting face-to-face in order to discuss the content of our memos and the extent to which similar codes and themes emerged. We also assessed the need for further analysis and if we had achieved theoretical and empirical saturation.

\section{Findings}

Here we structure our discussion of findings in the same order of our aforementioned research questions: Using photovoice, how do participating students make sense of educational and cultural experiences in a short-term study abroad? In what ways did participating students perceive the shortterm study abroad experiences as shaping and informing their knowledge of educational leadership?

\section{Photovoice-Capturing the Lived Human Experiences of Students Abroad}

The subjects of the 144 photos that were submitted varied widely, ranging from sweeping landscapes (e.g., Machu Picchu) the mundane (e.g., recycling bins, a teacher's desk), to the very personal. Space limitations prevent the inclusion of many (and certainly not all) photos. Furthermore, we vetted the photos to prevent the identification of any individuals from the United States or Peru. In such instances, we discuss the corresponding student narratives.

Our analysis revealed a number of themes, including the application of Bolman and Deal's four frames, Peruvian culture and society, Peruvian education, and Peruvian-U.S. comparisons (see Table 1). Three of the four students chose to categorize their photovoice selections using Bolman and Deal's four frames. One student (Naomi) did not refer at all to Bolman and Deal's four frames in her photovoice assignment. The three remaining students applied Bolman and Deal's framework to both contemporary Peruvian organizations and historic ones (e.g., Incan Empire). However, most captured educational settings. Indeed, Pauline only referenced Bolman and Deal (2013) with photos and narratives focusing on educational institutions and the communities they serve. 
Table 1. Photovoice Codes and Themes

\begin{tabular}{|c|c|c|c|c|c|c|}
\hline Theme & Code & Frequency & Pauline & Tricia & Ann & Naomi \\
\hline \multirow{4}{*}{ Four Frames } & Symbolic Frame & 29 & $\mathrm{X}$ & $\mathrm{X}$ & $\mathrm{X}$ & \\
\hline & Structural Frame & 28 & $\mathrm{X}$ & $\mathrm{X}$ & $\mathrm{X}$ & \\
\hline & Human Resource Frame & 17 & $\mathrm{X}$ & $\mathrm{X}$ & $\mathrm{X}$ & \\
\hline & Political Frame & 13 & $\mathrm{X}$ & $\mathrm{X}$ & $\mathrm{X}$ & \\
\hline \multirow{5}{*}{$\begin{array}{l}\text { Peruvian Culture \& } \\
\text { Society }\end{array}$} & Travel Experiences & 22 & & $\mathrm{X}$ & $\mathrm{X}$ & $\mathrm{X}$ \\
\hline & History & 8 & $\mathrm{X}$ & $\mathrm{X}$ & $\mathrm{X}$ & $\mathrm{X}$ \\
\hline & Culture & 11 & $\mathrm{X}$ & $\mathrm{X}$ & $\mathrm{X}$ & $\mathrm{X}$ \\
\hline & Catholic Influence & 6 & $X$ & $\mathrm{X}$ & $X$ & $\mathrm{X}$ \\
\hline & $\begin{array}{l}\text { Role of Women in Education \& } \\
\text { Peruvian Society }\end{array}$ & 4 & & $\mathrm{X}$ & $\mathrm{X}$ & \\
\hline \multirow{5}{*}{ Peruvian Education } & Rural-Urban Divide in Peru & 5 & $\mathrm{X}$ & $\mathrm{X}$ & & $\mathrm{X}$ \\
\hline & $\begin{array}{l}\text { Peruvian Educational Leadership } \\
\text { Practices }\end{array}$ & 4 & $\mathrm{X}$ & $\mathrm{X}$ & & \\
\hline & $\begin{array}{l}\text { P-12 Education Institutions \& } \\
\text { Scenes }\end{array}$ & 34 & $\mathrm{X}$ & $\mathrm{X}$ & $\mathrm{X}$ & $\mathrm{X}$ \\
\hline & $\begin{array}{l}\text { Postsecondary Education } \\
\text { Institutions \& Scenes }\end{array}$ & 11 & $\mathrm{X}$ & $\mathrm{X}$ & $\mathrm{X}$ & $\mathrm{X}$ \\
\hline & Peruvian Education Policy & 4 & $\mathrm{X}$ & $\mathrm{X}$ & & \\
\hline \multirow{2}{*}{$\begin{array}{l}\text { Peruvian-US } \\
\text { Comparisons }\end{array}$} & Peruvian-US Commonalities & 12 & & $\mathrm{X}$ & $\mathrm{X}$ & $X$ \\
\hline & Peruvian-US Contrasts & 6 & & $\mathrm{X}$ & $\mathrm{X}$ & $\mathrm{X}$ \\
\hline
\end{tabular}

In terms of frequency, students referenced the symbolic frame the most. For example, Pauline provided a montage of crests representing the educational institutions (elementary, secondary, and postsecondary) that she and the other students visited. She stated that, "These crests are symbolic of what each school or university holds important. Common symbols include groupings of threes, stars, crowns and lions." 'Tricia provided two exemplar applications of the symbolic frame to educational organizations. One was at the classroom level (see Figure 2). She explained:

, a private Catholic school in Lima, has a reward system for students who strive to meet the school's expectations. Four symbols are posted around the school that the students can gain ownership of if appointed by a teacher. The crown (of the Virgin Mary) represents service, the sword (strength to change things) represents justice, the mountain represents effort and the energy to reach your goals, and the stars represent happiness.

\section{Figure 2. Symbolic Frame: Classroom-level}

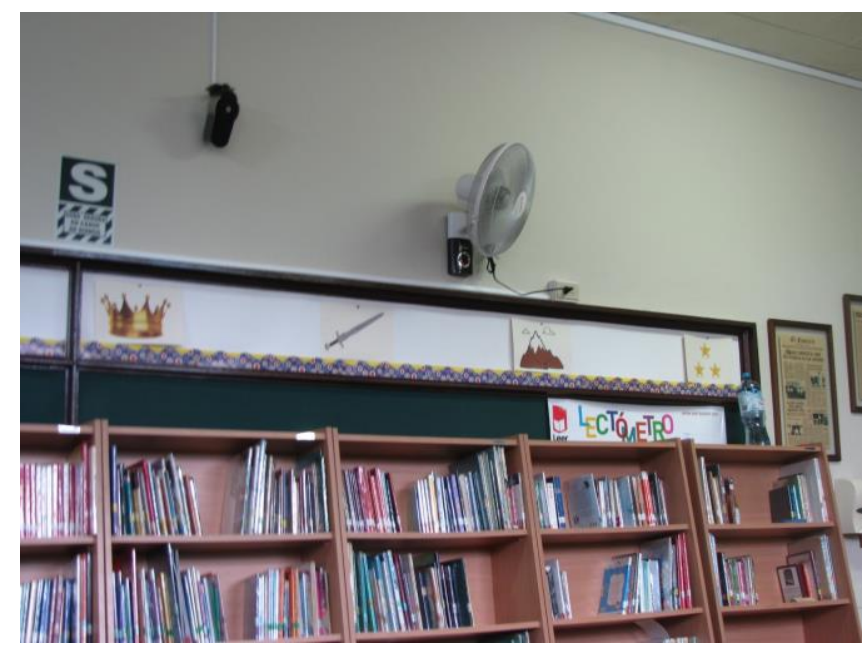


The second example that Tricia provided makes connections between symbols seen in schools that represent Peruvian history and culture. She described a photo (see Figure 3), stating:

All across Peru, you will see a recurring trio of animals: the condor, puma, and serpent. The condor represents the upper world, God. The puma represents the earthly world, humans. The serpent represents the underworld, the dead. I enjoyed this mural that was in a school library because it also shows other symbols that are representative of Cusco, Peru.

Second in frequency were students' references to structural aspects of organizations. Ann provided a picture of rules for a K-12 classroom (see Figure 4). She stated that, "In the U.S., classroom rules and norms are expected to be posted for students to see. Peruvian classrooms have the same expectation." This photo and the accompanying text touch on a second theme that emerged from our analysis-Peruvian-U.S. comparisons, such that students provided evidence of comparing and contrasting their Peruvian observations and experiences with those in the United States. Consistent across the students' comparisons were how their experiences as students abroad gave them perspectives about how it must feel to be a member of a racial minority and language minority. These realizations began upon arrival in Lima, but were further reinforced when in Andean Peru. The few students who had some fluency in Spanish were at a disadvantage when in the Quechua-speaking area of Peru.

Figure 3. Symbolic Frame: Mural on a School Library

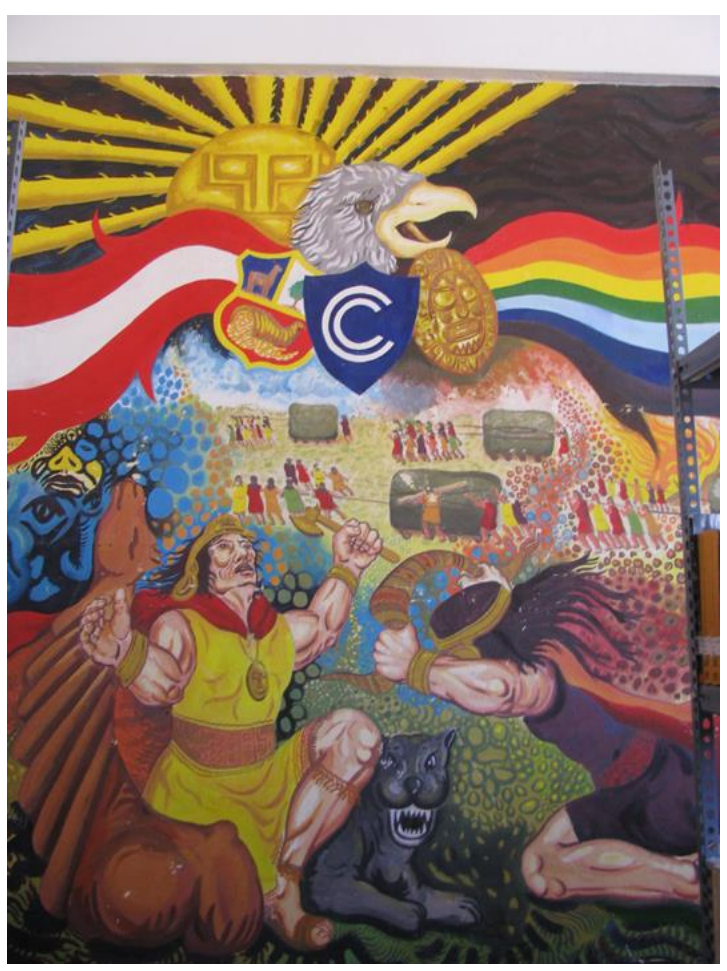


Figure 4. Structural Frame: Rules posted in a classroom

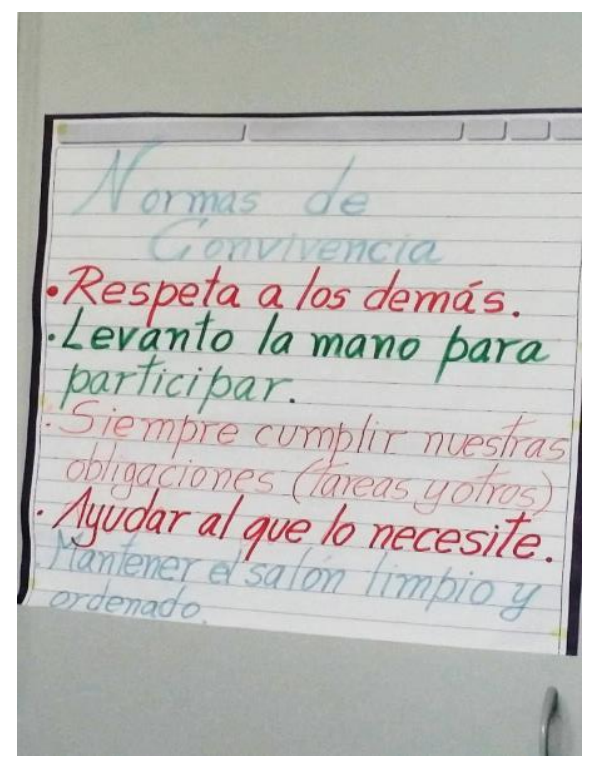

Among Bolman and Deal's four frames, the human resource frame was referenced third most in frequency. For example, Ann submitted a photo of a teachers' lounge at an affluent, private K-12 school in Lima (see Figure 5). She describes the photo, stating, "These pictures were taken in the teacher's lounge at -----. It is such a dramatic difference from any teacher's lounge I've been in that I had to take pictures, and that includes the most expensive schools in [my home state in the U.S]." Ann references both the human resource frame, seeing this as a physical space to facilitate the work of instructional staff, but also the political frame, noting the disparate educational conditions that are present in Peruvian schools, some of which serve the very privileged and powerful elite in Peru's capital.

Figure 5. Human Resource Frame: Teachers' Lounge in an Affluent Private School

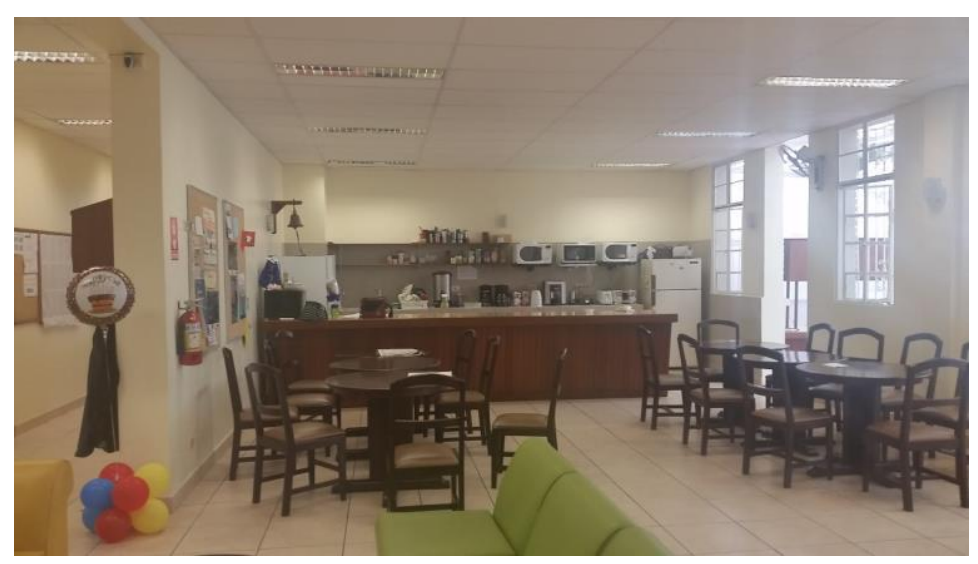

Tricia submitted a photo and accompanying narrative that represents the importance of the human resource frame, but from a rural, Andean educational context (see Figure 6). In the photo, one sees Peruvian women in the Andes pushing wheelbarrows. She describes the scene, stating: 
The heart and soul of any educational institute should be the parents. While parent involvement is lacking in some U.S. schools, it was very evident that these parents are very involved in Peruvian schools. This is a photo of several mothers who are carrying rocks to help build a playground for their kids at the new school that is being built in [the village of]

Figure 6. Human Resource Frame: Parents Building a Playground at a Rural Public School

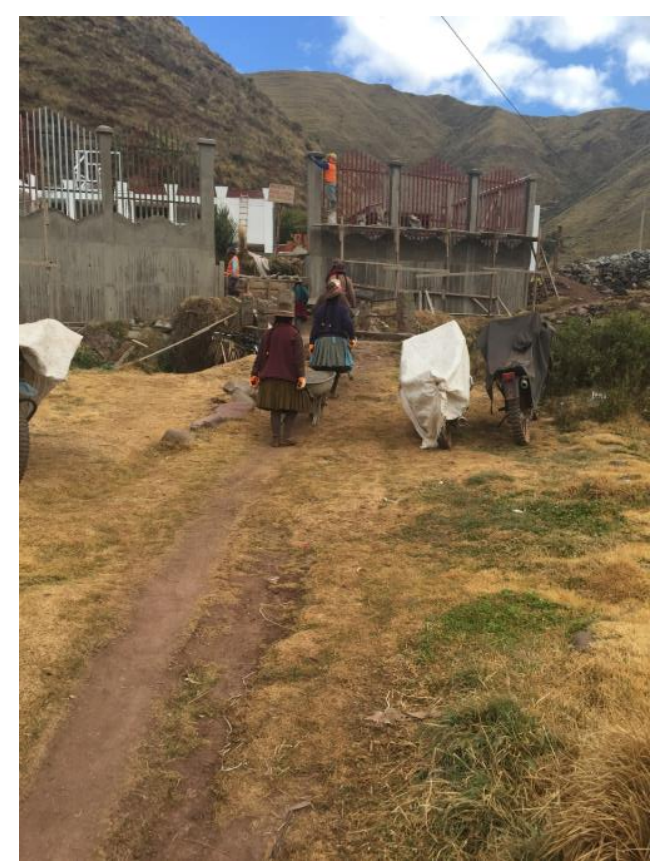

Students referenced the political frame in their photovoice assignments, but less frequently. Two particular subthemes emerged: party politics and access to scarce resources. With regard to the former, Ann submitted a picture of what was a common site in the Peruvian countryside- election campaign signs (see Figure 7). Ann stated:

Instead of yards littered with signs each October and May during election times, the citizens of Peru show their allegiance for a specific party or candidate by painting their houses, barns, or outbuildings. All through the countryside, there are remnants of a previous election. If you notice the date on the picture, you will note this sign was for an election that took place last year.

Ann submitted another photo of a small ceramic statue on display in a public school in Cusco. She stated that, "This little statue had a prominent position in the trophy case at The statue represents a triumphant win for a political party that supported the school." 
Figure 7. Political Frame: Election Campaign Signs

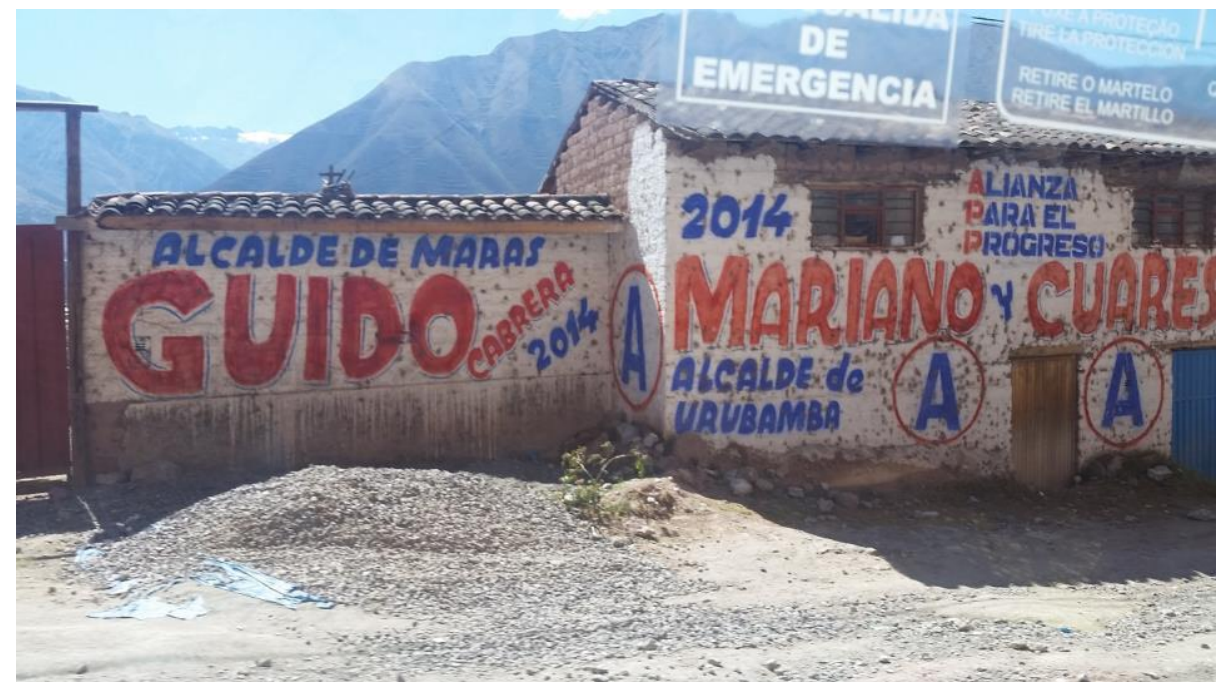

With regard to scarce resources, Tricia submitted a photo taken at a lecture given to the students at a university in Lima (see Figure 8). Tricia stated, "Resources are scarce for public schools in Peru. Below it shows the percentage of how many public schools in Peru are without electricity, internet, and running water."

As the short-term study abroad experience included visits to important historical and cultural sites, it is not surprising that all students submitted photos that captured historical and cultural aspects of Peru. Most notably, students submitted photos that document the influence that the Incan Empire has left on contemporary Peru. These were in the form of photos from archaeological sites and museums, and photos of the native descendants that inhabit present-day Peru. The students also noted the cultural influence that the Roman Catholic Church has had on education and culture in Peru. Naomi submitted a photo of the Blanco Cristo (White Christ) statue that sits atop a mountainside above Cusco. Students also submitted photos and narratives that captured other important aspects of Peruvian culture, including native foods, street scenes, religious festivals, religious rituals, and products for sale in marketplaces. Pauline, for example, submitted a photo with the following narrative:

At -----------, we observed a yearly ceremony that was meant to bless the potatoes that would soon be planted. The ceremony incorporated potatoes, coca leaves, sweet wine and cola in shells, a certain flower and animal fat. The ritual was filmed by the school's video camera to preserve the students' heritage and to be used later in lessons. The potatoes were blessed and a few were planted by the elders and the rest by the students. Afterward the school's "Yacha" [village elders] spoke to the children about why the ceremony was important to the culture of the Andean people. 
Figure 8. Political Frame: Access to Electricity, Internet, and Running Water

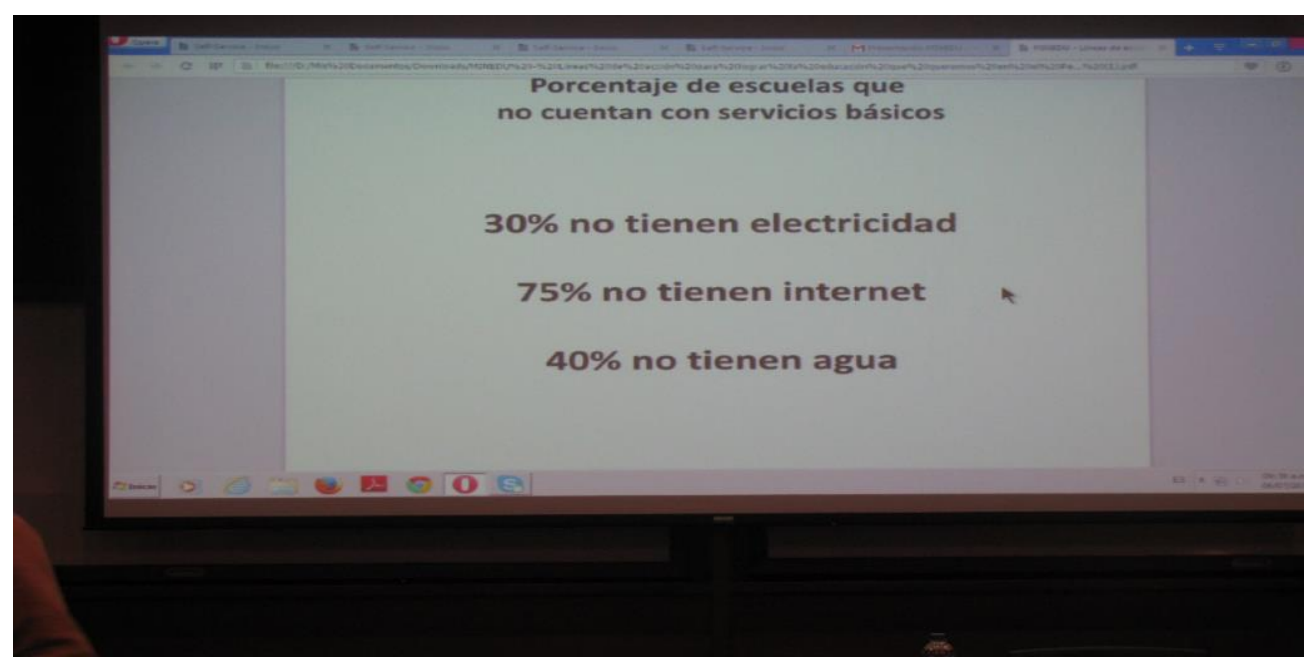

Given that all of our students were educators, it is not surprising that 34 of the photos captured school scenes, such as facilities, students, teachers, or principals at work. One photo submitted by Naomi captures elementary children in a public school in Cusco. Naomi’s accompanying text states:

Primary students head into their technology class. Though the secondary classroom we visited was sparsely populated, this classroom held 37 boys who looked to be somewhere between the ages of 6 and 8 . There was only one teacher in the room for all of those students! She did a brilliant job with classroom management!

Similarly, Ann submitted a photo of a " $2^{\text {nd }}$ grade classroom at a private Catholic school in Lima. The classroom is equipped with a projector, teacher computer, lots of age appropriate books, bean bag chairs, student sized chairs, and a thick rug for students to sit on during reading times.”

Through the photovoice assignment, students provided evidence of comparing and contrasting their educational environments in the United States and those in Peru, documenting scenes that were both relatable to and vastly different from their own experiences. Notably, students documented more commonalities than contrasts. For example, Naomi noted that, "A teacher's desk is a teacher's desk is a teacher's desk" (see Figure 9). Naomi concluded her photovoice assignment with a photo and accompanying narrative that summed up her study abroad experience in Peru (see Figure 10). She stated, "I will be forever grateful for every stain on my clothes and shoes and every bruise on my knees that our time in Peru brought me, for they represent the most generous and welcoming culture I've ever met." 
Figure 9. A Teacher's Desk

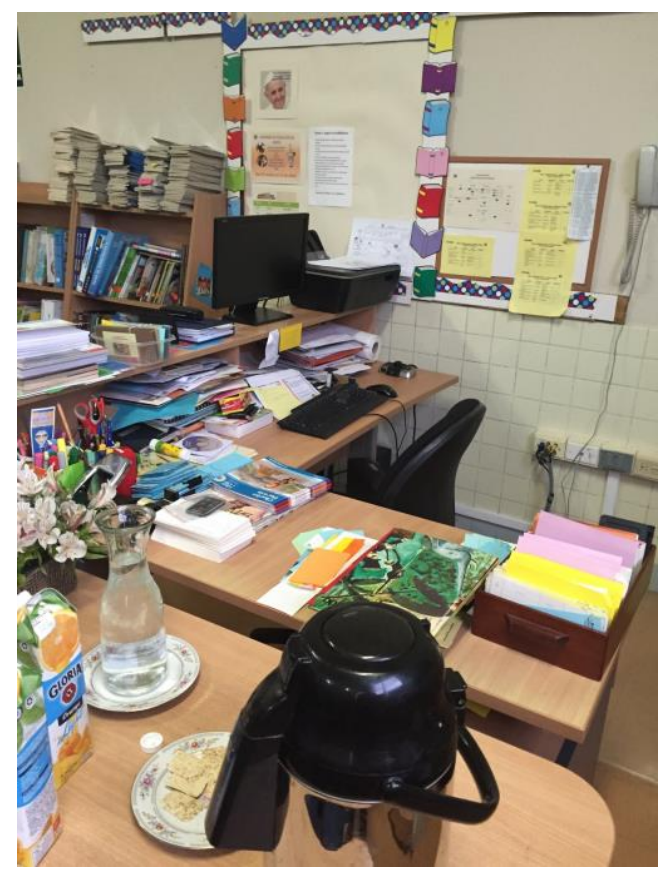

\section{Informing Educational Leadership through Study Abroad}

The students experienced a whirlwind of sights, sounds, perspectives, and experiences in both educational (schools, universities) and cultural settings (museums, archaeological sites), but how did students perceive these experiences as shaping and informing their knowledge of educational leadership? Unsurprisingly, our analysis of course assignments revealed that students drew upon their own professional backgrounds and experiences as K-12 practitioners to make sense of their educational experiences abroad. Indeed, the course's official title was Comparative Perspectives of Educational Leadership and Diversity.

Students identified a wide-ranging number of educational leadership-related topics (see Table 2). Some were consistent across all of the students, largely explained by the shared experiences (e.g., lectures, museum visits, tours) that the students had. Others represented distinct interests, individual perspectives, and insights gleaned from the study abroad experience. We coded and themed the reflective journal entries using Bolman and Deal's four frames in order to understand how the various experiences shaped and informed their knowledge of educational leadership. 
Figure 10. Dirty Shoes, Warm Heart

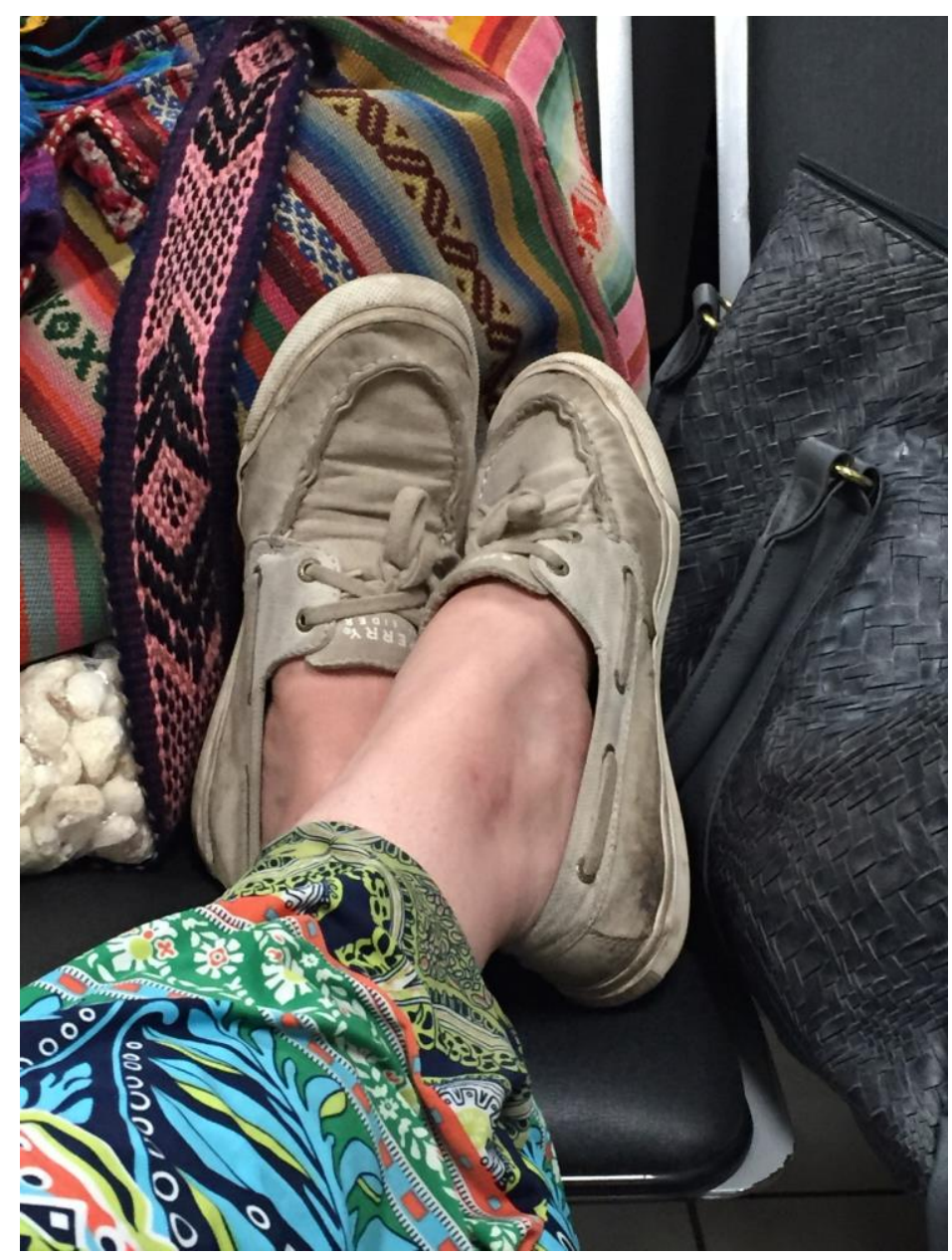

Nine codes were consistent across all four graduate students: Incan/Pre-Columbian Influences, Catholic Influences, U.S.-Peru Comparisons, School Leadership, Non-Profit Partners, Educational Resources, Policies, Rural-Urban Divide, and Social Justice. Having shared many planned experiences such as visits to important historical and archaeological sites, students consistently wrote about ways in which Incan and Spanish influences (i.e., Catholicism) merged to shape what is now contemporary Peru. For example, Ann stated:

The city of Lima, with its ten million people is an amazing place. The symbolism, seen everywhere you look, shows a society steeped in ceremonies and spirituality. The Catholic and Incan powers waged war long ago for dominance in Peru, and while it seems the Spanish won the Battle of Cajamarca and Catholicism prevailed, there are many symbols and signs of Incan influence throughout the country. 
Table 2. Reflective Journaling and Final Paper Coding

\begin{tabular}{|c|c|c|c|c|c|}
\hline Theme & Code & Pauline & Tricia & Ann & Naomi \\
\hline \multirow{7}{*}{ Structural } & Curriculum-Arts in Education & & & & $\mathrm{X}$ \\
\hline & Discipline Policies & $\mathrm{X}$ & $\mathrm{X}$ & & $\mathrm{X}$ \\
\hline & Liability & & & $\mathrm{X}$ & \\
\hline & Research-based Practices & & $\mathrm{X}$ & $\mathrm{X}$ & \\
\hline & Scheduling & $\mathrm{X}$ & & & $\mathrm{X}$ \\
\hline & School leadership & $\mathrm{X}$ & $\mathrm{X}$ & $\mathrm{X}$ & $\mathrm{X}$ \\
\hline & Teacher Compensation Policies & $\mathrm{X}$ & $\mathrm{X}$ & $\mathrm{X}$ & \\
\hline \multirow{10}{*}{ Human Resources } & Bilingual Instruction & & $\mathrm{X}$ & $\mathrm{X}$ & \\
\hline & Class Sizes & & & & $\mathrm{X}$ \\
\hline & Community Members' Contributions & & $\mathrm{X}$ & $\mathrm{X}$ & \\
\hline & Drugs and Alcohol Prevention & $\mathrm{X}$ & $\mathrm{X}$ & & $\mathrm{X}$ \\
\hline & Provision of Special Education & $\mathrm{X}$ & $\mathrm{X}$ & & \\
\hline & Experiencing Life as a Minority & & & & $\mathrm{X}$ \\
\hline & Gender roles in Education & & $\mathrm{X}$ & & $\mathrm{X}$ \\
\hline & Kids are Kids & & & $\mathrm{X}$ & $\mathrm{X}$ \\
\hline & Non-profit Partners & $\mathrm{X}$ & $\mathrm{X}$ & $\mathrm{X}$ & $\mathrm{X}$ \\
\hline & Professional Learning Communities & & $\mathrm{X}$ & & \\
\hline \multirow{6}{*}{ Political } & Educational Resources & $\mathrm{X}$ & $\mathrm{X}$ & $\mathrm{X}$ & $\mathrm{X}$ \\
\hline & Equity and Access to Education & & $\mathrm{X}$ & & $\mathrm{X}$ \\
\hline & Teacher Compensation & $\mathrm{X}$ & $\mathrm{X}$ & $\mathrm{X}$ & \\
\hline & Policies & $\mathrm{X}$ & $\mathrm{X}$ & $\mathrm{X}$ & $\mathrm{X}$ \\
\hline & Rural-Urban Divide & $\mathrm{X}$ & $\mathrm{X}$ & $\mathrm{X}$ & $\mathrm{X}$ \\
\hline & Social Justice & $\mathrm{X}$ & $\mathrm{X}$ & $\mathrm{X}$ & $\mathrm{X}$ \\
\hline \multirow{3}{*}{ Symbolic } & Catholic Influences & $\mathrm{X}$ & $\mathrm{X}$ & $\mathrm{X}$ & $\mathrm{X}$ \\
\hline & Incan/Pre-Columbian Influence & $\mathrm{X}$ & $\mathrm{X}$ & $\mathrm{X}$ & $\mathrm{X}$ \\
\hline & School Symbols & $\mathrm{X}$ & $\mathrm{X}$ & & \\
\hline Peru-US Comparisons & Peru-US Comparisons & $\mathrm{X}$ & $\mathrm{X}$ & $\mathrm{X}$ & $\mathrm{X}$ \\
\hline Summary & Summary Perspectives & $\mathrm{X}$ & $\mathrm{X}$ & & $\mathrm{X}$ \\
\hline \multirow{4}{*}{ Final Paper Topics } & Profile of Two Community Agencies & $\mathrm{X}$ & & & \\
\hline & Diversity in the Peruvian Curriculum & & $\mathrm{X}$ & & \\
\hline & Comparison of Political Structures in the US and Peru & & & $\mathrm{X}$ & \\
\hline & $\begin{array}{l}\text { Comparing Perceptions of Public Education in an Urban } \\
\text { High School and a Rural Peruvian School }\end{array}$ & & & & $\mathrm{X}$ \\
\hline
\end{tabular}

Students connected the pre-Columbian and colonial history of Peru to the present educational context in which educational leaders must operate. Students noted the prominence of Catholic education in Peru. A number of factors drove this prominence. Students referenced the spread of Catholicism by the conquering Spanish, but learned through readings and lectures from Peruvian-based experts about the nexus of compulsory education laws and concerns about the quality of public school education in Peru. The latter stemmed from inadequate government support for public education, which in turn led to teacher strikes and school closures. These factors exacerbated the proliferation of Catholic schools (World Bank 6). Students contrasted the historical evolution of Peru and the United States, highlighting the separation of church and state in the U.S. educational system and its absence in Peru. Students also drew parallels between U.S. education and Peruvian education, noting the development of standards, assessment, and accountability systems in both nations. Students also identified parallels between the proliferation of Catholic schools in Peru and charter schools in the United States.

When visiting school sites in rural Andean Peru that serve indigenous Quechua-speaking communities, students connected what they learned at museums and archaeological sites to contemporary practices in schools. Tricia described one such experience at a rural, Andean school site: 
To start the day off, they sang the national anthem for us and then we heard one of the six yachas [elders] discuss the agenda for the day. First up was an activity that we had to travel down to a neighboring farm to see. Once a month, there is a ceremony that helps keep the old traditions alive. TAREA [an educational non-profit] helps the schools become involved with these ceremonies so that the students can learn more about their heritage. The activity that the students did today was one centered on harvesting wheat. There were three roles in this activity; students who carried down the wheat (males), students who used the pitch forks (primarily male), and students who swept up the wheat (primarily female). This activity was split into a couple of different sessions and the students took breaks in between. During the first break, we were invited to be involved in a ritual to thank mother earth. We used three coca leaves that we dipped in wine and thanked the mountains before placing our leaves in a pile. Once all of the members of our group, the students, teachers, and yachas had placed their leaves in a pile, one of the yachas had put the coca leaves into a fire. According to the yacha in ------, it is going to be a good year and harvest since the smoke was white, the yachas said that it was going to be a good year. The elders in the community discussed a variety of ways to use nature (weather, plants and animals) to determine how the year was going to go and when to plant their crops.

All of the students captured the themes of lectures delivered by Peruvian Ministry of Education officials, TAREA ${ }^{2}$ representatives, and leading Peruvian scholars from the fields of education policy and economics in their reflective journaling. These included multiple policy levels and educational reforms to which Peruvian teachers and educational leaders must respond; the policies and politics behind teacher compensation in Peru; the inequitable distribution of access and resources across Peruvian schools and regions (notably the rural-urban divide); the slow pace of progress for social justice in the provision of education in Peru; and the role of non-profit partners in Peruvian education. These, in turn, led students to reflect on parallels in policy and practice in the U.S. context. Naomi, for example, referenced a lecture and discussion led by a Peruvian-based faculty member:

Dr. ------- made a comment that I believe will stick with me for the rest of my life. He said that public policy "can damage not just a life, but generations." I think a lot about that in reference to both what's going on here in Peru but also in the United States, where we are very aware of gaps in both academic achievement and incidents of discipline. Since beginning the doctoral program, I have read countless articles that say the same things - African American students are disciplined at a much higher rate, and perform lower academically than their White peers. We know this, and we know some of the reasons why this is happening: poverty and the issues that accompany it (illiteracy, malnutrition, etc.), lack of cultural competency in classrooms, and of course the decreased instructional time that comes from increased classroom exclusion due to discipline issues, just to name a very few. We know this, and yet we continue to maintain the same policies that continue to damage generations of students.

Indeed, all of the students acknowledged disparities across U.S. schools and districts and noticed similar disparities in Peru. The students toured some of the most privileged and modern school sites in Peru as well as some of the most squalid ones. Students referenced the high-quality school facilities and technology in the highly privileged schools_-even expressing a certain level of jealousy for the facilities, as the Peruvian schools were nicer than the ones in their own school districts. Likewise, the study abroad students realized that in spite of serving in some of their communities' most impoverished

\footnotetext{
${ }^{2}$ TAREA, a non-profit that seeks to develop equitable, intercultural, bilingual education policies and practices,
} provided lectures and aided in the logistics of site visits to two remote rural schools in the Peruvian Andes. 
schools, the conditions in their U.S. schools were an improvement upon the squalid conditions of the high-poverty schools visited in the Andes. A journal entry from Tricia captured her fellow students' reactions to the poverty and conditions within the school facilities, but she was not as shocked as her colleagues. Prior travel and teaching experiences abroad in a more impoverished context shaped her perspective:

Don't get me wrong, I had a very humbling experience at --------, however I feel like hearing everyone else's experience made me feel like they were more shell-shocked than I was by seeing the extreme poverty present in the school. While the new school in ------- will be very nice, the community center where they are holding classes temporarily was much nicer than the ones I taught in while in --------. In comparison, ------ has paved floors, electricity, technology (cameras and computer), and materials for students and teachers to use. While the school was nicer than ones I have been in before, ------- is still a school in high need of resources.

In spite of wide disparities between schools (private-public, urban-rural, Spanish-speakingQuechua-speaking), the students acknowledged that school leaders and teachers in the United States and Peru have an important job to do. Accompanying a picture from a high-poverty school in the Andes, Pauline stated, "Despite the scant resources, evident isolation, and very little government support, the teachers' morale and teaching skills were inspirational. One teacher has been there for over 25 years. Their leadership is what keeps this school going." Student journaling identified a variety of roles that Peruvian educational leaders assume as well as individual insights and observations from school site visits. These include the role of instructional leaders who facilitate a healthy school climate and culture (Hoy and Miskel 26). For example, Tricia discussed her observations of a private, Catholic school in Lima, stating, "The tone of a school is set by the administrators. I could tell just in the short time of visiting the school that Father ------ had a great rapport with his staff and students." In her reflective journaling, Ann noted the use of evidenced-based best practices proliferated by regional governments to inform leadership at the building level. Pauline saw parallels between Peru's principal standards and those used in principal preparation programs in the United States. She stated, "Another intriguing point Dr. ----- [Ministry of Education official] made is that three years ago, the government moved from having 127 regulations principals must deal with, to only eight . . These regulations remind me of the Interstate School Leaders Licensure Consortium (ISLLC) Standards for U.S. principals."

All four study abroad students expressed a keen interest in how educational leaders structure the learning environments in Peruvian schools and how these compare to schools in the United States. For example, Naomi described an urban school in the Andes, stating:

The school has both primary and secondary levels, and is an all-boys school. There are 2,700 registered students with 204 staff members (divided between teachers, administrators, and staff). The school is divided into three shifts . . . a morning shift, an afternoon shift, and an evening shift. There are 1,000 morning shift students, but then they accommodate more students in the afternoon and evening. The evening shift is primarily for secondary students who have dropped out and then decided to return to school, so it functions as a type of "alternative school." They have two administrative teams - one focuses on improving learning, and one focuses on behavioral management. When the principal spoke of typical behavioral issues, some of the issues he discussed are things that we see in school in the United States. It seems that "tardiness" is a universal struggle, and it warmed my heart to think that, all over the 
world, a bell starts ringing and a teenager starts running. However, some of the issues that they consider "behavioral issues" are more related to mental health in the United States . . . The principal spoke of alcohol and drug addiction, for example, as a behavioral problem instead of something that needs medical treatment. It is something we both deal with. We just happen to view it differently.

Lectures and school site visits with TAREA representatives reinforced concepts learned in prior graduate educational leadership coursework that focuses on identifying, engaging, and deploying community resources in support of student learning outcomes, including community agencies. The study abroad experience afforded a Peruvian example of a non-profit that supports goals and outcomes in education. Tricia discussed the role of TAREA:

TAREA does something called participative management, which builds plans around what the community wants and needs. Specifically, they learn from the yachas (elders) of their community. They want to keep the traditions intact for further generations so they focus on knowledge of language and understanding their community. What TAREA is doing in these rural schools is something I feel like public schools in America could benefit from.

Beyond the aforementioned codes shared across all four students, the remaining observations, experiences, and foci of reflective journal entries varied widely from student to student, focusing on a number of structural, human resource, political, and symbolic aspects of schools and their administration. Students tended to focus heavily on structural and human resource aspects of the sites that they visited. For example, one of Ann's journal entries captures a number of codes when she discusses observing an agricultural ceremony at a small rural school high in the Andes. She stated:

The children played specific roles in the ceremony, marching from a local farmhouse to a field that had been set up with a ring of harvested wheat. Some students had small rakes, some students had small brooms made from branches, and some were bystanders. The farmer brought his horse into the ring of wheat, and began leading the horse around the ring. While the horse tromped through the wheat, the students raked the excess wheat back into the ring, and the students with brooms went behind them and swept the leftover wheat back into the ring. The horse bounced and stomped around the ring, threshing the wheat over and over. During the process, all I could think about was the safety aspect, and how close the horse hooves came to children's heads. The students had a firm understanding of safety, and I wonder how much we rob from our students in the states for fear of a lawsuit if a child was mildly injured.

Ann's journal entry captures the influences of Incan culture in contemporary Peruvian education, the roles of adults and students in the education process, and Peruvian experiences that contrast with those in the United States, specifically a concern with the school's liabilities. Another student, Naomi, commented on the presence of the arts in one of the schools she visited:

At one point, I was pulled out of the meeting and was able to step into a classroom where some very young students were rehearsing a puppet show. As a theatre teacher, my heart swelled! It is wonderful to see the arts thriving in any culture or country. The kids were having a ton of fun, and it was wonderful for me to experience that.

In terms of the human resource aspects of the schools they visited, students wrote journal entries discussing the provision of education in Spanish as well as indigenous languages, class sizes, 
community members' involvement in education, how a school is addressing drug and alcohol use/abuse, gender roles observed in Peruvian education, and professional learning communities. Although the students consistently discussed contrasts in policies and practices between the United States and Peru, they also noted that despite being from different countries, schoolchildren are still schoolchildren wherever you go. Naomi stated:

I made eye contact with three little boys who were hiding cookies under their desk. We made eye contact, and smiled at each other. I bent over and whispered, "Tienes comida en clase? No comida en clase!” The boys giggled and offered a cookie to me. I thanked them but didn't take one, and I thought how adorable and generous these silly little boys were.

In closing their journals, three of the four students offered some summary perspectives of their experiences in Peru. Consistent across the participating students was the transformative power of the study abroad experience. Naomi expressed, “I'll never be the same after my trip to Peru. I think that's exactly what the university had in mind when they put us on the airplane." Naomi discussed how her experience abroad provided a new perspective and appreciation for the experiences of minority students and those who do not speak English as their primary language in her school. She stated, "I had a moment to reflect on being a 'minority' and how it felt." Tricia stated:

This trip was such a blessing and I have learned so much in just two short weeks. Not only did I learn more about education and how to apply what I have learned in my own career path, but I learned so much about myself and life in general. When you are thrown into a situation where you are surrounded by strangers in a different country, you learn so many things about others and yourself to help grow as a person. I can definitely say that I have grown as a person and a professional because of the people whom I shared this educational experience with and this trip has produced many lasting memories that I will cherish forever.

Particularly moved by her site visit to a small rural school high in the Andes Mountains, Pauline wrote:

When we first walked up to the school that takes most students 1-3 hours to get to, I kept thinking these people have nothing; no running water, no electricity, long journeys to and from school or work and a hard, laborious life. The majority of people I live and work with will never know life such as this. However, as I walked away I realized everything these people did have: an eagerness to learn, generosity of spirit and a deep-seeded love for their environment.

The reflective journaling assignment provided students a means by which they could process their shared experiences as well as their personal insights into the experiences. Students documented both shared learning experiences and deeply personal perspectives of their study abroad.

One final assignment remained for students to complete - a final paper on a leadership topic of their choosing. Students selected a leadership topic that drew upon their international learning experiences, relevant extant research, lectures, and documents collected in Peru. Their chosen topics were wide-ranging, but all of the students undertook comparisons of conditions and/or practices in the United States and Peru. Pauline chose to profile three community agencies-two in her local school district and one in Peru. One of the two U.S. community agencies is dedicated to providing resettlement services to refugees through faith- and agency-based co-sponsorship in order to promote self-sufficiency and successful integration into the community. The other U.S. agency seeks to improve 
the quality of life of individuals, families, and youth in the community through the provision of a variety of social, educational, recreational, and cultural programs and services. Pauline featured the aforementioned non-profit organization, TAREA. She concluded that the work of these non-profits are aligned with the goals of the schools they seek to support and school leaders, whether in the United States, Peru, or elsewhere, should become more aware of such organizations and their missions, and leverage these community agencies and resources as much as possible. As she noted, "My experiences in Peru have reminded me how essential it is for school leaders to utilize community agencies for the betterment of all students."

Drawing upon site visits, lectures, discussions with school stakeholders, and documents collected in Peru, Tricia sought to examine the forms of diversity present in the curriculum of Peruvian schools. She compared these forms of diversity to those in her own school and district, citing ways that schools and educational systems in both countries inadequately address the needs of students who do not speak the predominant language. She touches upon the shortage of highly qualified bilingual teachers in both the United States and Peru. Given the pressures wrought by standards, assessments, and accountability systems in both countries, educational leaders have an incentive to address the needs of the various subpopulations they serve. Accountability data can show the extent to which progress is (or is not) present. She cautioned that regardless of whether in the United States or Peru, "teaching to the test limits the exploration and depth in the learning process."

Ann chose to compare the political structures and provision of education in the United States and Peru. She identified and discussed analogous organizations (Ministry of Education in Peru and Department of Education in the United States) and laws (No Child Left Behind in the United States; National Education Project in Peru), concluding that in both the United States and Peru, educational systems are challenged by inequalities in educational opportunities for children. In the case of the United States, impoverished and minority students suffer the most from these inequalities. In the case of Peru, students from indigenous, poor, and rural backgrounds suffer the most. She cites evidence (provided by the Peruvian experts) that there is positive news to report from Peru. Specifically, she draws upon data that suggest access to schooling is increasing, gender gaps have significantly narrowed, and public investment in education (percentage of GDP spent on education) is slowly increasing over time. She noted that in both countries, policies need to increase educational opportunities for marginalized student subpopulations, but funding inequities remain a barrier to progress.

Finally, Naomi profiled two schools-her large urban high school and a small rural school high in the Andes. She highlights that both school sites serve disadvantaged youth with dedicated teachers and school leaders that serve as positive change agents in their community, but in the case of her own school, negative media coverage and perceptions within the larger urban community overshadow the positivity within the school that occurs on a daily basis. In the case of the rural school in the Peruvian Andes, she highlighted the local community as supporting the work of the small number of teachers and principal, but noted the lack of national concern for students born into indigenous-speaking homes. Negative media coverage is not a problem. There is no coverage at all. The school is virtually unknown in Peru and to the outside world. Naomi concludes:

School and ------ High School are vastly different in so many ways. One is a primary school in the Andes with no electricity, plumbing, or road for easy access. The other is a 
secondary school in --------, easily accessed by roads and with technology, but plagued by negative media attention . . . Both schools are united in their desire for more from the larger community . . . Both schools are, in a way, underdogs, that will perhaps surprise anyone who decides to listen. Although the schools are thousands of miles, dollars, and cultures apart, they find common ground.

\section{Summary and Implications}

Consistent across the participating students was the transformative power of the study abroad experience. Students drew upon their own professional experiences as well as prior or ongoing graduate course work in the United States to make sense of their educational experiences overseas. All of the students went to Peru acknowledging in their pre-departure papers that they had limited prior knowledge of the nation's past or present. Documents and photographs submitted by the students captured both striking similarities and contrasts. For example, one student stated, "Although Peru is a developing nation and the United States is one of the wealthiest countries in the world, both places see great disparities in the distribution of wealth, which unfortunately means that the educational experiences of students in both nations are vastly different." Students noted that while U.S. schools struggle with the provision of education to ESL students, Peruvian schools also struggle with students who speak languages other than Spanish, i.e., Quechua and other indigenous languages. Students were consistent in their recognition of the historical and cultural power of the Roman Catholic Church in Peru as shaping both the symbolic, political, and structural frames of educational organizations. In spite of the passage of time, students also saw how native pre-Columbian history and culture continues to shape that of present-day Peru, as evidenced by symbolism, art, and the curriculum. Participating students also noted the contrasts of student experiences within Peru. The disparate conditions across the state, private, and parochial schools of Lima and those in rural school settings in the Andes consistently affected the students. Students paralleled the experiences of students in their native U.S. state with those of Peru. As one student noted, "It seems like Peru struggles with the same issues as -------, with an urban and rural divide."

These four study abroad students became active participants, voicing their experiences, perspectives, and analyses through the photographs that they took and submitted. The photos captured a wide array of subjects, ranging from historical sites, cultural sites, and artifacts to Peruvian people, schools, and classrooms. Not surprisingly, P-12 educational institutions and scenes predominated the pictures and accompanying text in the photovoice submissions. Students captured the beauty of the Peruvian people, cityscapes, and countryside as well as the contrasting conditions of rural schools in comparison to those in the capital city of Lima. While students acknowledged the differences between Peru and the United States, students found more in common than not. Although the structured nature of international-country travel to historical and educational sites ensured that students had some common educational experiences and opportunities for learning, students still had the flexibility to explore topics of most interest to them through questions posed to speakers, tour guides, and hosts at educational institutions and cultural sites. Students actively sought to learn more or see specific things at these sites.

The students' experiences in Peru provided them with opportunities to compare and contrast education, leadership, policy, and practices in Peru with their own in the U.S. educational context. The study abroad experience provided them the opportunity to see the similarities and differences in a 
personal and experiential way. Their foci on educational leadership and policy-related topics ranged from the importance of community agencies in supporting the work of educators to national education policies' influence on local schooling and instruction related to providing instruction to students who do not speak the dominant language. Consistent across the students was how their experiences in Peru flipped the script on the perspective of being a minority student and being a speaker of a language other than the predominant language. Their experience in Peru gave them a window into the world of so many students in their U.S. schools - what it is like to be a racial and language minority. This empathy enriched and informed their perspectives as educators and future educational leaders.

In terms of implications for the planning and delivery of short-term study abroad learning experiences, there are some broad recommendations that are true of any short-term study abroad program. These experiences require careful and thoughtful planning in order to maximize the utility of these programs. Participating students and facilitating faculty members need flexibility in order to respond and adapt to conditions "on the ground" and in real time. Short-term study abroad experiences are valuable as evidenced by the narratives provided by the participating students. However, the provision of these programs is cost-prohibitive and can limit the number of students who participate. In the case of the participating institution, private donors were able to subsidize the tuition of the participating students, but not all institutions of higher learning can be so fortunate. Cooperative agreements, student exchanges, and prioritizing need-based scholarships may aid in the expansion of these programs to students with lesser means.

As Richardson et al. noted, the quality of pre-departure, in-country, and debriefing experiences influence the overall study abroad experiences of students (365). An implication specific to this study abroad experience also emerged-instructors must be critical of their instructional methods and assessments used in such study abroad experiences. Three of four photovoice assignments were structured around Bolman and Deal's Four Frames, which is not surprising given that the professor of record provided it as a means for students to make sense of their study abroad experience given little prior knowledge of Peruvian history, culture, or the nation's provision of education. Symbolic and structural frame-related pictures dominated the submissions. The instructor's intent was to facilitate an opportunity for students to be active participants and give "voice" to their "experiences, perspectives, and analyses through the photographs that they take" (Barndt 620). While well-intentioned, the use of broadly applicable theoretical frameworks such as Bolman and Deal's four frames (2013) may impinge upon the students' freedom to express themselves through the photovoice assignment. Instructors should seek a balance between the analytical constraints of such heuristics with the freedom that photovoice promises. Despite explicitly stating that "students are not solely constrained to using this framework," one wonders whether the selection of photos and accompanying text would have been different had the instructor not mentioned Bolman and Deal's theoretical framework in association with the assignment.

Very few scholars have (i.e., Richardson et al. 356) examined leadership development through study abroad experiences, but small n-sizes hampered those studies and the present one. Like Richardson et al., future research may want to utilize both qualitative and quantitative data sources in research that examines multiple cohorts of study abroad participants, thus increasing $\mathrm{n}$-sizes and obtaining the depth of qualitative data. Annually recurring programs offer a rich opportunity to 
examine the delivery and experience over time. Optimally, each iteration leads to improvements and lessons learned.

\section{References}

Andrews, Deborah C., and Brent Henze. "Teaching Professional Writing to American Students in a Study Abroad Program." Business Communication Quarterly, vol. 72, 2009, pp. 5-20. doi: 10.1177/1080569908330382

Annang, Lucy, et al. "Photovoice: Assessing the Long-Term Impact of a Disaster on a Community's Quality of Life." Qualitative Health Research, vol. 26, no. 2, 2016, pp. 241-251. doi: 10.1177/1049732315576495

Barndt, Deborah. "Photovoice." The SAGE Encyclopedia of Action Research, edited by David Coghlan and Mary Brydon-Miller, SAGE, 2014, pp. 620-623.

Barnes, Sandra L. "Black Church Culture and Community Action." Social Forces, vol. 84, no. 2, 2005, pp. 967-994.

Bolman, Lee G., and Terrence E. Deal. Reframing Organizations: Artistry, Choice and Leadership. $5^{\text {th }}$ ed., Jossey-Bass, 2013.

Briggs, Lilly P., et al. "Photo-Elicitation Methods in Studies of Children's Sense of Place." Children, Youth and Environments, vol. 24, no. 3, 2014, pp. 153-172.

Brooks, Jeffrey, and Anthony H. Normore. "Educational Leadership and Globalization: Literacy for a Global Perspective." Educational Policy, vol. 24, no. 1, 2010, pp. 52-82.

Castañeda, Martha E., and Megan L. Zirger. "Making the Most of the 'New' Study Abroad: Social Capital and the Short-Term Sojourn." Foreign Language Annals, vol. 44, no. 3, 2011, pp. 544-564. doi: 10.1111/j.1944-9720.2011.01146.x

Chanse, Victoria, et al. "New Approaches to Facilitate Learning from Youth: Exploring the Use of Photovoice in Identifying Local Watershed Issues." Journal of Environmental Education, vol. 48, no. 2 , 2017, pp. 109-120. doi: 10.1080/00958964.2016.1256260

Colville-Hall, Susan, et al. "Franco-American Teachers-in-Training: A Study of Best Practices in Teaching and Studying Abroad." Frontiers: The Interdisciplinary Journal of Study Abroad, vol. 21, 2011, pp. 275288.

Di Pietro, Giorgio. "Do Study Abroad Programs Enhance the Employability of Graduates?" Education Finance \& Policy, vol. 10, no. 2, 2015, pp. 223-243. doi:10.1162/EDFP_a_00159

Dollarhide, Colette, et al. "New Counselors' Leadership Efforts in School Counseling: Themes from a YearLong Qualitative Study." Professional School Counseling, vol. 11, no. 2, 2008, pp. 262-271.

Engle, Lilli, and John Engle. "Study Abroad Levels: Toward a Classification of Program Types." Frontiers: The Interdisciplinary Journal of Study Abroad, vol. 9, 2003, pp. 1-20.

Fine, Janis B., and Krista W. McNamara. "Community Redefined: School Leaders Moving from Autonomy to Global Interdependence through Short-Term Study Abroad." Frontiers: The Interdisciplinary Journal of Study Abroad, vol. 21, 2011, pp. 254-274.

Fleming-May, Rachel A., and Kimberly Douglass. "Framing Librarianship in the Academy: An Analysis Using Bolman and Deal's Model of Organizations." College \& Research Libraries, vol. 75, no. 3, 2014, pp. 389-416.

Flessa, Joseph. "Educational Micropolitics and Distributed Leadership." Peabody Journal of Education, vol. 84, no. 3, 2009, pp. 331-349.

Freire, Paulo. Pedagogy of the Oppressed. Continuum, 1970.

Goldenberg, Barry M. "White Teachers in Urban Classrooms: Embracing Non-White Students' Cultural Capital for Better Teaching and Learning." Urban Education, vol. 49, no. 1, 2014, pp. 111-114.

Grissom, Jason A., et al. "Using Student Test Scores to Measure Principal Performance." Educational Evaluation and Policy Analysis, vol. 37, no. 1, 2015, pp. 3-28. 
Hallinger, Phillip, and Junjun Chen. "Review of Research on Educational Leadership and Management in Asia: A Comparative Analysis of Research Topics and Methods, 1995-2012." Educational Management and Leadership, vol. 43, no. 1, 2015, pp. 5-27.

Harper, Douglas. "Talking about Pictures: A Case for Photo Elicitation.” Visual Studies, vol. 17, no. 1, 2002, pp. 13-26. doi: 10.1080/14725860220137345

Heimovics, Richard D., et al. "Executive Leadership and Resource Dependence in Nonprofit Organizations: A Frame Analysis." Public Administration Review, vol. 53, no. 5, 1993, pp. 419-427.

Hill, Bob, and Noel Thomas. "Making Sense of Bali: Unintended Outcomes of Study Abroad Programs." Teaching Education, vol. 16, no. 3, 2005, pp. 197-211. doi: 10.1080/10476210500204879

Hirschheim, Rudy, and Mike Newman. "Symbolism and Information Systems Development: Myth, Metaphor and Magic." Information Systems Research, vol. 2, no. 1, 1991, pp. 29-62.

Hoy, Wayne K., and Cecil G. Miskel. Educational Administration: Theory, Research, and Practice, $9^{\text {th }}$ Edition. McGraw-Hill, 2013.

Inman, Duane, et al. "Exploring Diverse Cultures with Undergraduate Education Students." Journal of the Association of Independent Liberal Arts Colleges of Teacher Education, vol. 1, 2004, pp. 17-29.

Institute of International Education. "Profiles of US Study Abroad Students, 2004/05-2015/16." Open Doors Report on International Educational Exchange, 2017, https://www.iie.org/opendoors.

Jackson, Dimitra Lynette. "Balancing Act: Impacting and Initiating the Success of African American Female Community College Transfer Students in STEM into the HBCU Environment." Journal of Negro Education, vol. 82, no. 3, 2013, pp. 255-271. doi: 10.7709/jnegroeducation.82.3.0255

Julien, Heidi, et al. "Photovoice: A Promising Method for Studies of Individuals' Information Practices." Library \& Information Science Research, vol. 35, no. 4, 2013, pp. 257-263. doi: 10.1016/j.lisr.2013.04.004

Kelley, Matthew. "Collaborative Digital Techniques and Urban Neighborhood Revitalization." Social Work, vol. 56, no. 2, 2011, pp. 185-188.

Leithwood, K., et al. How Leadership Influences Student Learning. Wallace Foundation, 2004.

Lindsey, Randall, et al. The Culturally Proficient School: An Implementation Guide for School Leader, Second Edition. Corwin Press, 2013.

Mamary, Edward, et al. "Our Lives: An Examination of Sexual Health Issues Using Photovoice by Non-Gay Identified African American Men Who Have Sex with Men. Culture, Health \& Sexuality, vol. 9, no. 4, 2007, pp. 359-370. doi: 10.1080/13691050601035415

Mayan, Maria J., et al. "Punishing Progress and Expecting Failure: Alberta Families' Experiences Accessing Social Service Systems." Canadian Social Work Review / Revue Canadienne de Service Social, vol. 28, no. 1, 2011, pp. 107-126.

McPhail, Christine Johnson, et al. "The Cohort Leadership Development Model: Student Perspectives." Community College Journal of Research and Practice, vol. 32, 2008, pp. 362-374. https://doi.org/10.1080/10668920701884539

Normore, Anthony H., and Nancy Erbe. Collective Efficacy: Interdisciplinary Perspectives on International Leadership. Emerald Group Publishing, 2013.

Orahood, Tammy, et al. "The Impact of Study Abroad on Business Students' Career Goals." Frontiers: The Interdisciplinary Journal of Study Abroad, vol. 10, no. 7, 2004, pp. 117-130.

Paige, R. Michael, et al. "Study Abroad for Global Engagement: The Long-Term Impact of Mobility Experiences." Intercultural Education, vol. 20, no. 1, 2009, pp. S29-S44. doi: $10.1080 / 14675980903370847$

Phillion, JoAnn, et al. "Reimagining the Curriculum: Future Teachers and Study Abroad." Frontiers: The Interdisciplinary Journal of Study Abroad, vol. 18, 2009, pp. 323-339.

Relich, Joseph D., and Michael Kindler. "Canadian Students Down Under: An Intercultural Perspective for Teacher Training in Australia." Frontiers: The Interdisciplinary Journal of Study Abroad, vol. 2, 1996, pp. 64-82. 
Richardson, Jayson W., et al. "Evaluating Leadership Development through a Study Abroad Experience." International Journal of Leadership in Education, vol. 17, no. 3, 2014, pp. 353-369. doi: 10.1080/13603124.2013.817611

Richardson, Jayson W., et al. "Developing Culturally Aware School Leaders: Measuring the Impact of an International Internship Using the MGUDS." Educational Administration Quarterly, vol. 49, no. 1, 2013, pp. 92-123. doi: 10.1177/0013161X12455055

Sjoberg, Sandra D., and Olga I. Shabalina. "More than a Sight-Seeing Trip: Enhancing the Value in ShortTerm Study Abroad.” Business Education Innovation Journal, vol. 2, 2010, pp. 46-58.

Sleeter, Christine. "Epistemological Diversity in Research on Preservice Teachers Preparation for Historically Underserved Children." Review of Research in Education, vol. 25, 2001, pp. 209-250.

Sowell, Steven. "Building a New Paradigm: Analysis of a Case Study in Organizational Change in Collection Management Using Bolman's and Deal's Four-Frame Mode." Collection Management, vol. 39, no. 2-3, 2014, pp. 211-226.

Stephenson, Sandria S. "Faces' and Complexities of Continuing Higher Education Units: A Postmodern Approach." Journal of Continuing Higher Education, vol. 58, 2010, pp. 62-72.

Thompson, Jennifer. "II am a farmer": Young Women Address Conservation Using Photovoice around Tiwai Island, Sierra Leone." Agenda: Empowering Women for Gender Equity, vol. 79, 2009, pp. 65-69.

Teichler, Ulrich, and Wolfgang Steube. "The Logics of Study Abroad Programmes and their Impacts." Higher Education, vol. 21, no. 3, 1991, pp. 325-349. doi: 10.1007/BF00132724

Tinsley, Howard E., and D J. Weiss. "Interrater Reliability and Agreement of Subjective Judgements." Journal of Counseling Psychology, vol. 22, 1975, pp. 358-376. doi: 10.1037/h0076640

Tinsley, Howard E., and David J. Weiss. "Interrater Reliability and Agreement." Handbook of Applied Multivariate Statistics and Mathematical Modeling, edited by Howard E. Tinsley and Steven D. Brown, Academic Press, 2000, pp. 95-124.

UNESCO. City of Cusco, whc.unesco.org/en/list/273.

Werts, Amanda B., et al. "Representing Embodiment and the Policy Implementing Principal Using Photovoice." Journal of Educational Administration, vol. 50, no. 6, 2012, pp. 817-844. doi: $10.1108 / 09578231211264702$

Werts, Amanda B., and Curtis A. Brewer. "Reframing the Study of Policy Implementation: Lived Experience as Politics." Educational Policy, vol. 29, no. 1, 2015, pp. 206-229. doi: 10.1177/0895904814559247

Wiers-Jensen, Jannecke. "Career Impacts of Student Mobility: Stumbling Block or Stepping Stone?" Borderless Knowledge, edited by Ase Gornitzka and Liv Langfeldt, Springer, 2008, pp. 79-101.

Womble, Lynsee, et al. "A Model for Designing Faculty-Led Study Abroad Programs in the Business Curriculum." Academy of Educational Leadership Journal, vol. 18, no. 3, 2014, pp. 93-110.

World Bank. Peruvian Education at a Crossroads: Challenges and Opportunities for the 21 st Century. World Bank, 2001.

Zenkov, Kristien, and James Harmon. "Picturing a Writing Process: Photovoice and Teaching Writing to Urban Youth." Journal of Adolescent \& Adult Literacy, vol. 52, no. 7, 2009, pp. 575-584. doi: 10.1598/JAAL.52.7.3 


\section{Appendix A: course syllabus}

\section{UNIVERSITY}

\section{LEAD 6XX: Comparative Perspective of Educational Leadership \& Diversity (3 Credit Hours) \\ Summer 2015}

Meeting Days \& Times:
Classroom Location:
Instructor:
Office:
Phone:
E-Mail
Office Hours:
appointment

Meeting Days \& Times: Classroom Location:

Instructor:

Office:

E-Mail appointment

\section{Catalog Description}

The course offers the student an opportunity to expand their conceptions on international perspectives of leadership preparation with emphasis on leadership development in Lima and Cusco, Peru. This class is designed to explore and understand educational leadership formation in an international context, and how that compares to educational leadership formation in the US. Specifically, students will explore school leadership formation and role in Peru, particularly in the contexts of two main areas. The first one is how educational leadership preparation and roles are being shaped by the current decentralization efforts in the Peruvian government. For instance, Peru's national government has traditionally been heavily centralized, and decisions were made based on the predominant perspectives in Lima. This ties with the second area-students will explore how the dominant approaches to educational leadership, which have been based on Spanish-speaking realities contrast and are undertaken in areas with high presence of Quechuaspeaking children and respond to diverse populations.

\section{Course Purpose}

Through a short-term graduate study abroad experience, educational leadership students will undertake an intercultural immersion in Peru, visiting multiple Peruvian educational organizations and participating in lectures and discussions with university faculty, administrator, teachers, and students.

\section{Required Texts}

Bolman, L.G., \& Deal, T.E. (2013). Reframing organizations: Artistry, choice and leadership, $5^{\text {th }}$ edition. San Francisco: Jossey-Bass.

World Bank. (2001). Peruvian education at a crossroads: Challenges and opportunities for the $21^{\text {st }}$ century. Washington DC: World Bank. [available electronically at the course Blackboard site]

\section{$\underline{\text { Additional Required Readings or Resources }}$}


Fine, J.B., \& McNamara, K.W. (2011). Community redefined: School leaders moving from autonomy to global interdependence through short-term study abroad. Frontiers: The Interdisciplinary Journal of Study Abroad, 21, 254-274.

Hill, B., \& Thomas, N. (2005). Making sense of Bali: Unintended outcomes of study abroad programs. Teaching Education, 16(3), 197-211.

Werts, A.B., Brewer, C.A., \& Mathews, S.A. (2012). Representing embodiment and the policy implementing principal using photovoice. Journal of Educational Administration, 50(6), 817-844.

World Bank. (2007). World Bank - Education in Peru. Retrieved from https://www.youtube.com/watch?v=-BxL1aqb6mY

\section{Student Learning Outcomes_-Relevant Professional Standards Met by Course}

\section{National Standards:}

The ISLLC Standards addressed most fully by this course are:

Standard 4: An education leader promotes the success of every student by collaborating with faculty and community members, responding to diverse community interest and needs, and mobilizing community resources.

Collect and analyze data and information pertinent to the educational environment

Promote understanding, appreciation, and use of the community's diverse cultural, social, and intellectual resources

Build and sustain positive relationships with families and caregivers

Build and sustain productive relationships with community partners

Standard 5: An education leader promotes the success of every student by acting with integrity, fairness, and in an ethical manner.

Ensure a system of accountability for every student's academic and social success

Model principles of self-awareness, reflective practice, transparency, and ethical behavior

Safeguard the values of democracy, equity, and diversity

Consider and evaluate the potential moral and legal consequences of decision making

Promote social justice and ensure that individual student needs inform all aspects of schooling

\section{Course Objectives}

Through the international learning academic experience, students will be able to:

Articulate initial ideas about the impact of global research on enlarging their conceptions about leadership preparation.

Synthesize current research on leadership development and preparation

Examine the preparation process for school leaders globally.

Compare and contrast the leadership development process in Peru with leadership preparation in the United States.

Compare and contrast major issues in educational reform and educational leadership practice (i.e. teacher evaluation reform, common core, merit pay, charter school movement) that span their current US educational context (school-level, district-level, state-level, and national-level).

Articulate informed perspectives, enlightenment, and new understandings about leadership preparation, diversity, and the pursuit of social justice through comparative analysis and reflection.

\section{Conceptual Framework Summary}

Deleted to protect the identity of the university. 


\section{Relationship to Conceptual Framework}

Deleted to protect the identity of the university.

Policy on Instructional Modifications

Deleted to protect the identity of the university.

Diversity Statement

Deleted to protect the identity of the university.

\section{Note on Late Work}

Late work will be accepted only if discussed with the beforehand. Incomplete grades must be negotiated prior to the end of the semester, and if an incomplete grade is given, it will be granted for only one semester.

\section{Policy on Instructional Modifications}

Deleted to protect the identity of the university.

\section{Diversity Statement}

Deleted to protect the identity of the university.

\section{Plagiarism Statement}

Deleted to protect the identity of the university.

\section{University Policy on Sexual Misconduct}

Deleted to protect the identity of the university.

\section{Grading Scale}

$97 \quad-100$

94-96

90-93

$87-89$

$84-86$

$80-83$

$77-79$
$\mathrm{A}+$

A

A-

$\mathrm{B}+$

$\mathrm{B}$

$\mathrm{B}-$

$\mathrm{C}+$

\section{Determination of Grade}

Attendance/Participation

Pre-Departure Reflection

20 points

Reflective Journaling

20 points

20 points

Photovoice

Final Paper 20 points 20 Points

TOTAL $=100$ Points

Course Requirements

\begin{tabular}{|l|l|}
\hline Assignment & Points \\
\hline Attendance \& Participation & 20 \\
$\begin{array}{l}\text { Active participation and attendance at all pre-departure briefings, in-country briefings and } \\
\text { debriefings, site visits, and post-experience debriefings are critical. It is expected that students }\end{array}$ & \\
\hline
\end{tabular}




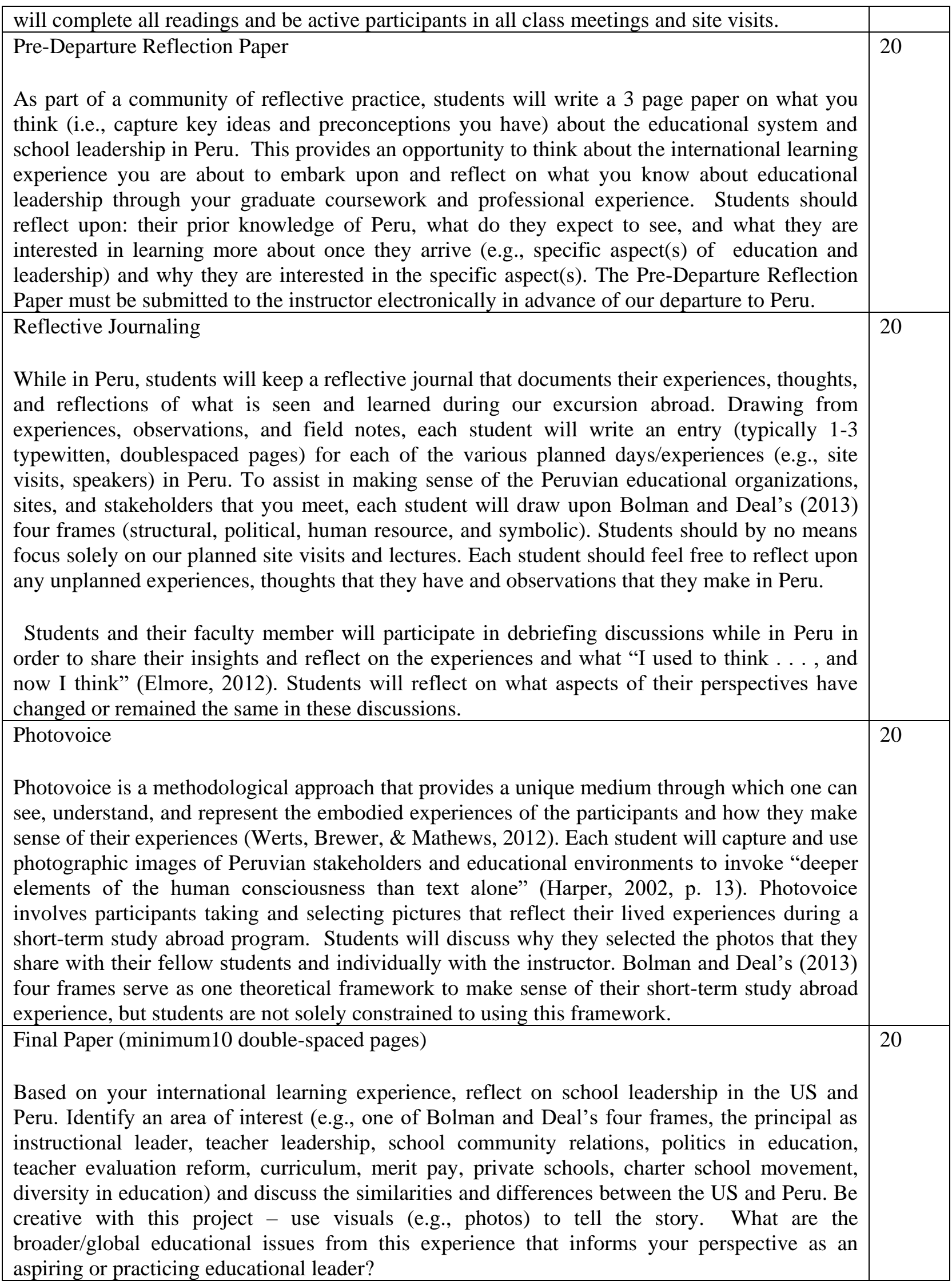




\section{Appendix B: Rubrics}

Rubric for Pre-Departure Reflection Paper (20 points)

\begin{tabular}{|c|c|c|c|}
\hline CRITERION & $\begin{array}{l}\text { Unacceptable } \\
0 \text { points }\end{array}$ & $\begin{array}{l}\text { Acceptable } \\
\text { (3 points) }\end{array}$ & $\begin{array}{l}\text { Target } \\
(5 \text { points })\end{array}$ \\
\hline $\begin{array}{l}\text { Prior } \\
\text { Knowledge }\end{array}$ & $\begin{array}{l}\text { Student fails to discuss their } \\
\text { prior knowledge or state that } \\
\text { (s)he has no prior knowledge of } \\
\text { Peru at all. }\end{array}$ & N/A & $\begin{array}{l}\text { Student discusses their } \\
\text { prior knowledge or states } \\
\text { that (s)he has no prior } \\
\text { knowledge of Peru at all. }\end{array}$ \\
\hline Expectations & $\begin{array}{l}\text { Student fails to discuss what } \\
\text { (s)he expect to see in Peru or } \\
\text { their bases for their expectations }\end{array}$ & $\begin{array}{l}\text { Student fails to } \\
\text { discuss one of the } \\
\text { following: } \\
\text { 1. what (s)he expects } \\
\text { to see in Peru, or } \\
\text { 2. their bases for } \\
\text { these expectations }\end{array}$ & $\begin{array}{l}\text { Student discusses what } \\
\text { (s)he expects to see in } \\
\text { Peru and their bases for } \\
\text { these expectations }\end{array}$ \\
\hline $\begin{array}{l}\text { Learning } \\
\text { Interests }\end{array}$ & $\begin{array}{l}\text { Student fails to discuss what } \\
\text { (s)he is interested in learning } \\
\text { more about or why (s)he is } \\
\text { interested in these specific } \\
\text { aspect(s) }\end{array}$ & $\begin{array}{l}\text { Student fails to } \\
\text { discuss one of the } \\
\text { following: } \\
\text { 1. what (s)he is } \\
\text { interested in learning } \\
\text { more about, or } \\
\text { 2. why (s)he is } \\
\text { interested in these } \\
\text { specific aspects. }\end{array}$ & $\begin{array}{l}\text { Student discusses what } \\
\text { (s)he is interested in } \\
\text { learning more about and } \\
\text { why (s)he is interested in } \\
\text { these specific aspect(s) }\end{array}$ \\
\hline APA & $\begin{array}{l}\text { 4+ errors in APA formatting, } \\
\text { spelling, or grammar. }\end{array}$ & $\begin{array}{l}\text { 1-3 errors in APA } \\
\text { formatting, spelling, } \\
\text { or grammar. }\end{array}$ & $\begin{array}{l}\text { No APA formatting, } \\
\text { spelling, or grammar } \\
\text { issues }\end{array}$ \\
\hline
\end{tabular}


Rubric for Reflective Journaling (20 points)

\begin{tabular}{|c|c|c|c|}
\hline CRITERION & $\begin{array}{l}\text { Unacceptable } \\
0 \text { points }\end{array}$ & $\begin{array}{l}\text { Acceptable } \\
(3 \text { points })\end{array}$ & $\begin{array}{l}\text { Target } \\
(5 \text { points })\end{array}$ \\
\hline $\begin{array}{l}\text { Expe } \\
\text { Sumr } \\
\text { Refle }\end{array}$ & $\begin{array}{l}\text { Journaling lack adequate } \\
\text { detail that summarizes the } \\
\text { experiences for each of the } \\
\text { various planned } \\
\text { days/experiences (e.g., site } \\
\text { visits, speakers) in Peru. }\end{array}$ & $\begin{array}{l}\text { Journaling provides some } \\
\text { detail that summarizes the } \\
\text { experiences for each of the } \\
\text { various planned } \\
\text { days/experiences (e.g., site } \\
\text { visits, speakers) in Peru. }\end{array}$ & $\begin{array}{l}\text { Journaling provides a } \\
\text { high degree of detail that } \\
\text { summarizes the } \\
\text { experiences for each of } \\
\text { the various planned } \\
\text { days/experiences (e.g., } \\
\text { site visits, speakers) in } \\
\text { Peru. }\end{array}$ \\
\hline $\begin{array}{l}\text { Col } \\
\text { Ret }\end{array}$ & $\begin{array}{l}\text { Reflection lacks critical } \\
\text { thinking. Superficial } \\
\text { connections are made with } \\
\text { educational leadership } \\
\text { concepts, readings, content, } \\
\text { and experiences (e.g., site } \\
\text { visits, speakers) in Peru. }\end{array}$ & $\begin{array}{lr}\text { Reflection } & \text { demonstrates } \\
\text { some degree of critical } & \text { of } \\
\text { thinking in applying, } \\
\text { analyzing, } \\
\text { evaluating and/or } \\
\text { leadership educational } \\
\text { readings, content, and } \\
\text { experiences (e.g., site visits, } \\
\text { speakers) in Peru. } \\
\text { Connections made through } \\
\text { explanations, inferences, } \\
\text { and/or examples. }\end{array}$ & $\begin{array}{l}\text { Reflection demonstrates a } \\
\text { high degree of critical } \\
\text { thinking in applying, } \\
\text { analyzing, and evaluating } \\
\text { educational leadership } \\
\text { concepts, readings, } \\
\text { content, and experiences } \\
\text { (e.g., site visits, speakers) } \\
\text { in Peru. Insightful and } \\
\text { relevant connections } \\
\text { made through contextual } \\
\text { explanations, inferences, } \\
\text { and examples. }\end{array}$ \\
\hline $\begin{array}{l}\text { Writing } \\
\text { Quality }\end{array}$ & $\begin{array}{l}4+\text { errors } \text { in } \text { APA } \\
\text { formatting, spelling, or } \\
\text { grammar. }\end{array}$ & $\begin{array}{l}1-3 \text { errors in } \text { APA } \\
\text { formatting, spelling, or } \\
\text { grammar. }\end{array}$ & $\begin{array}{l}\text { No APA formatting, } \\
\text { spelling, or grammar } \\
\text { issues }\end{array}$ \\
\hline Tim & $\begin{array}{l}\text { Journaling undertaken } \\
\text { every three or more days. }\end{array}$ & $\begin{array}{l}\text { Journaling undertaken on } \\
\text { an every other day basis }\end{array}$ & $\begin{array}{l}\text { Journaling undertaken on } \\
\text { a daily basis. }\end{array}$ \\
\hline
\end{tabular}

Rubric for Photovoice Assignment (20 points)

\begin{tabular}{|l|l|l|l|}
\hline CRITERION & $\begin{array}{l}\text { Unacceptable } \\
\text { 0 points }\end{array}$ & $\begin{array}{l}\text { Acceptable } \\
\text { (3 points) }\end{array}$ & $\begin{array}{l}\text { Target } \\
\text { (5 points) }\end{array}$ \\
\hline $\begin{array}{l}\text { Quantity of } \\
\text { photo } \\
\text { selections }\end{array}$ & $\begin{array}{l}\text { Student submits less than 14 } \\
\text { photos }\end{array}$ & $\begin{array}{l}\text { Student submits 14-19 } \\
\text { photos }\end{array}$ & $\begin{array}{l}\text { Student submits 20+ } \\
\text { photos }\end{array}$ \\
\hline $\begin{array}{l}\text { Experiential } \\
\text { Summary \& } \\
\text { Description }\end{array}$ & $\begin{array}{l}\text { Reflections lack detail that } \\
\text { inadequately summarizes } \\
\text { what the student } \\
\text { experienced, wh the } \\
\text { student sought to capture, } \\
\text { and why they selected the } \\
\text { photos for this assignment. }\end{array}$ & $\begin{array}{l}\text { Reflections adequate detail that } \\
\text { sumarizes what the } \\
\text { student experienced, what } \\
\text { the student sought to } \\
\text { capture, and why they } \\
\text { selected the photos for this } \\
\text { assignment. }\end{array}$ & $\begin{array}{l}\text { Reflection provides a } \\
\text { high degree of detail } \\
\text { that summarizes what } \\
\text { the } \\
\text { experienced, what the } \\
\text { student sought to } \\
\text { capture, and why they } \\
\text { selected the photos for } \\
\text { this assignment. }\end{array}$ \\
\hline $\begin{array}{l}\text { Content } \\
\text { Reflection }\end{array}$ & $\begin{array}{l}\text { Reflections lacks critical } \\
\text { thinking or provides }\end{array}$ & $\begin{array}{l}\text { Reflections provide } \\
\text { adequate critical thinking or }\end{array}$ & $\begin{array}{l}\text { Reflections provide a } \\
\text { high degree of critical }\end{array}$ \\
\hline
\end{tabular}




\begin{tabular}{|c|c|c|c|}
\hline & $\begin{array}{l}\text { superficial connections to } \\
\text { educational leadership } \\
\text { concepts or historical, } \\
\text { sociopolitical, economic } \\
\text { content covered in readings, } \\
\text { lectures, and/or study abroad } \\
\text { experiences (e.g., site visits, } \\
\text { speakers) in Peru. }\end{array}$ & $\begin{array}{l}\text { provides superficial } \\
\text { connections to educational } \\
\text { leadership concepts or } \\
\text { historical, sociopolitical, } \\
\text { economic content covered } \\
\text { in readings, lectures, and/or } \\
\text { study abroad experiences } \\
\text { (e.g., site visits, speakers) } \\
\text { in Peru. }\end{array}$ & $\begin{array}{l}\text { thinking or provides } \\
\text { superficial } \\
\text { connections to } \\
\text { educational leadership } \\
\text { concepts or historical, } \\
\text { sociopolitical, } \\
\text { economic content } \\
\text { covered in readings, } \\
\text { lectures, and/or study } \\
\text { abroad experiences } \\
\text { (e.g., site visits, } \\
\text { speakers) in Peru. }\end{array}$ \\
\hline $\begin{array}{l}\text { Writing } \\
\text { Quality }\end{array}$ & $\begin{array}{l}\text { 4+ errors in APA formatting, } \\
\text { spelling, or grammar in the } \\
\text { reflections that accompany } \\
\text { the photo selections }\end{array}$ & $\begin{array}{l}1-3 \text { errors in APA } \\
\text { formatting, spelling, or } \\
\text { grammar in the reflections } \\
\text { that accompany the photo } \\
\text { selections }\end{array}$ & $\begin{array}{l}\text { No APA formatting, } \\
\text { spelling, or grammar } \\
\text { issues in the } \\
\text { reflections } \\
\text { accompany the photo } \\
\text { selections }\end{array}$ \\
\hline
\end{tabular}

Rubric for Final Paper (20 points)

\begin{tabular}{|c|c|c|c|}
\hline CRITERION & Unacceptable (0 pts) & Acceptable (3 pts) & Target (5 pts) \\
\hline Completeness & $\mid \begin{array}{l}\text { Several sections of the } \\
\text { assignment } \\
\text { (introduction, area of interest, } \\
\text { similarities, differences, } \\
\text { educational/leadership issues, } \\
\text { conclusion) were not clearly } \\
\text { addressed, and lacked explicit } \\
\text { attention to the details. }\end{array}$ & $\begin{array}{l}\text { Most sections of the } \\
\text { assignment (introduction, } \\
\text { area of interest, similarities, } \\
\text { differences, } \\
\text { educational/leadership } \\
\text { issues, conclusion) were } \\
\text { addressed, but the written } \\
\text { product lacked explicit } \\
\text { detail in certain sections. }\end{array}$ & $\begin{array}{l}\text { Each section of the } \\
\text { assignment } \\
\text { (introduction, area of } \\
\text { interest, similarities, } \\
\text { differences, } \\
\text { educational/leadership } \\
\text { issues, conclusion) was } \\
\text { clearly and explicitly } \\
\text { addressed. }\end{array}$ \\
\hline Accuracy & $\begin{array}{l}\text { The author frequently fails to } \\
\text { support evidence presented } \\
\text { throughout the paper. The } \\
\text { concepts presented in the } \\
\text { paper are not cited, and do not } \\
\text { clearly connect to the readings } \\
\text { or other content from the } \\
\text { study abroad experience. }\end{array}$ & \begin{tabular}{|l} 
Most points made by the \\
authors are supported clearly \\
by cited evidence. The \\
authors often refer to \\
concepts learned in class, \\
and generally cite evidence \\
from readings and other \\
sources throughout the \\
paper.
\end{tabular} & $\begin{array}{l}\text { Points made by the } \\
\text { authors are supported } \\
\text { clearly } \text { by rited } \\
\text { evidence. The authors } \\
\text { refer to concepts learned } \\
\text { in class, and properly } \\
\text { cite evidence from } \\
\text { readings and other } \\
\text { sources throughout the } \\
\text { paper. }\end{array}$ \\
\hline Analysis & \begin{tabular}{||l} 
The main ideas and \\
arguments in the paper are not \\
identifiable. The authors fail \\
to highlight their analysis of \\
implicit \\
explicitly. The assumptions \\
arguments
\end{tabular} & $\begin{array}{l}\text { The main ideas and } \\
\text { arguments in the paper are } \\
\text { sometimes identified. The } \\
\text { authors generally identify } \\
\text { and highlight their analysis } \\
\text { of implicit assumptions. The }\end{array}$ & $\begin{array}{l}\text { The main ideas and } \\
\text { arguments in the paper } \\
\text { are identified explicitly. } \\
\text { The authors identify and } \\
\text { highlight their analysis } \\
\text { of implicit assumptions. }\end{array}$ \\
\hline
\end{tabular}




\begin{tabular}{|c|c|c|c|}
\hline & $\begin{array}{l}\text { presented are frequently } \\
\text { incoherent and internally } \\
\text { inconsistent. The authors } \\
\text { generally fail to provide } \\
\text { evidence when supporting } \\
\text { their arguments. }\end{array}$ & $\begin{array}{llr}\text { arguments } & \text { presented } & \text { are } \\
\text { mostly } & \text { coherent } & \text { and } \\
\text { internally } & \text { consistent. The } \\
\text { authors sometimes provide } \\
\text { evidence when supporting } \\
\text { their arguments. }\end{array}$ & 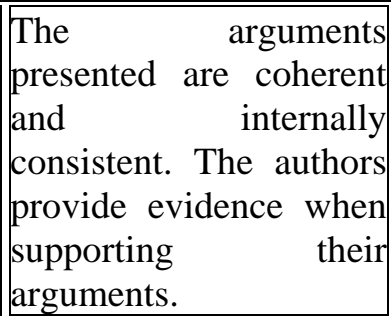 \\
\hline \begin{tabular}{|l|} 
Quality \\
Writing
\end{tabular} & $\begin{array}{l}\text { of } \\
\text { Che paper is not: } \\
\text { Clear to the reader } \\
\text { Succinct and not wordy } \\
\text { Well organized } \\
\text { APA compliant }\end{array}$ & $\begin{array}{l}\text { The paper is mostly: } \\
\text { Clear to the reader } \\
\text { Succinct and not wordy } \\
\text { Well organized } \\
\text { APA compliant }\end{array}$ & \begin{tabular}{|l|} 
The paper is: \\
Clear to the reader \\
Succinct and not wordy \\
Well organized \\
APA compliant
\end{tabular} \\
\hline
\end{tabular}

